\title{
Availability of Firms' Information and their Choice of External Credit: Evidence from the Data of Small Firms*
}

\author{
Wako Watanabe \\ Princeton University ${ }^{\dagger}$ \\ First draft: September 2003 \\ This version: March 2004
}

\begin{abstract}
The main purpose of this paper is to present the empirical findings derived from the data of small firms that the availability of private and public information on the borrowing firm leads to diverse borrowing patterns among firms. Exploring logit models to characterize the firm's choice of a financial source, we find that firms whose information is poorly recorded, or who are publicly less recognized, are more likely to choose institutional lending over trade credit but as the recorded information becomes more organized and firms become more transparent, they tend to graduate to a greater use of trade credit.

JEL Classification: C25, G21, G32

Keywords: availability of information, institutional lending, trade credit, nested logit models

*I would specially like to thank Ben Bernanke, Han Hong, and Guido Lorenzoni for their advice and encouragement. Thanks also to participants at the Princeton Macro/International Student Workshop and a public economics seminar at Keio University for their helpful comments. I thank Charles Yuji Horioka for his comments that improved the paper significantly. Any remaining errors are my own. I am also indebted to Courtney Carter of the Board of Governors of the Federal Reserve System for assisting

$\dagger$ Institute of Social and Economic Research, Osaka University, 6-1 Mihogaoka, Ibaraki, Osaka 567-0047, Japan. Email: watanabe@iser.osaka-u.ac.jp
\end{abstract} me with the data. 


\section{Introduction}

This paper intends to provide the empirical answer to the question: "Why do specialist financial intermediaries who engage solely in financial services exist?". The relevant answers have been addressed concerning banks that are the largest subset of specialist financial intermediaries. ${ }^{1}$ Freixas and Roche (1997) name four roles of a bank: offering access to a payment system, transforming assets (for instance, transforming of terms of assets), managing risk (of the investment project), and processing information and monitoring borrowers. They place emphasis on the fourth role, of managing asymmetric information, which, they claim, has been the major theoretical contribution of the last 20 years to our understanding of the banking function. They explain:

(I) $\mathrm{t}$ is reasonable to assume that banks have a specific part to play in managing some of the problems resulting from imperfect information on borrowers. Banks may invest in an informational technology that allows them to screen the different demands for loans they are confronted with and to monitor the projects, thus limiting the risk that the borrower may implement a project different from the one agreed upon initially.

Thus, the contemporary banking theory of asymmetric information restates the fundamental but vague question into the more manageable question: "Are specialist financial intermediaries advanced (efficient) in processing information (on borrowers) and monitoring borrowers?". Specialist intermediaries can exist on this ground insofar as they are more advanced (efficient) than other competing lenders that provide funds to the same customers. We know that the recent development of financial instruments allow various unintermediated financial instruments to fulfill transformation of assets and risk management. If specialist intermediaries lack informational advantages, the size of institutional loans must be negligible and only as large as that of the pooled funds required for the settlement of payment needs. The size of institutional loans in the real world, however, certainly exceeds this magnitude.

\footnotetext{
${ }^{1}$ It is not our intention to restrict the interpretation of our empirical findings to only banks since such specialist intermediaries include non-bank financial companies too.
} 
Small firms have been characterized as being bank dependent for their external financing as they are blocked from access to (unintermediated) financial markets, debt markets and equity market alike. Trade credit, on the other hand, has been analyzed rather as non-financial business practice among firms. In fact, however, trade credit can be viewed as a form of short term credit granted by firms supplying goods and services to buyer firms, and interestingly small firms are almost equally trade credit dependent. 43 percent and 37 percent of small firms' liability are trade credit and institutional borrowing, respectively. An analysis of small firms' financial decision must consider their liability management of two largest items. This approach also allows us comparison of financial institutions as specialist lenders with trade credit providing firms as non-specialist lenders. The stylized fact that small firms are blocked from corporate bond markets does not say much about the advantage of specialist financial intermediaries in presense of trade credit.

Using the 1998 Survey of Small Business Finances (SSBF) we investigated the relationship of the informational characteristics of the (small) firms and the pattern of their borrowing demand. In particular we explored how the managerial and accounting information of the firms is recorded and made available to the lenders and how the openness of the managerial decision making process, and the firms' public recognition lead to different borrowing patterns among them. We modeled the firm's borrowing application behavior with a discrete choice econometric model. Use of the data on the firms' applications for loans and trade credit, which include denied loans, allows us to identify borrowing demand and is superior to the conventional use of balance sheet data.

Our main findings are: 1 . Informationally opaque and less publicly known young firms are more likely to choose institutional loans over trade credit; 2. They tend to switch to trade credit as they become more established and publicly known, and are more forthcoming in recording detailed and accurate information on their management and accounting. Such findings support the notion of the informational advantage of institutional lenders.

The remainder of the paper is organized as follows. Section 2 discusses the background of our empirical exercise. While reviewing the related theoretical and empirical literature, it explains the contractual characteristics of trade credit and distinguishes it from the institutional lending based on its informational structure. Section 3 describes the data and introduces the empirical method. Section 4 shows and interprets the results. Section 5 concludes the paper. 


\section{Background and the Related Literature}

\subsection{The Costly State Verification Model}

The costly state verification model (Townsend, 1979; Williamson, 1987) shows that the lender's offer on the terms of contract reflects the cost that the lender expends to verify the state of the project the borrower firm exercises. $^{2}$ Since the higher cost of monitoring compresses the lender's expected profit from lending at any lending rate, the offering rate has to be forced up to make up for such loss of profit. The more efficient monitoring allows the lender to offer the cheaper funds to the firm. The firm compares contractual conditions that he would agree on with possible lenders and chooses the most favorable lender.

The size of the monitoring cost varies across lender-borrower pairs. It depends on the lender's monitoring technology, the borrower firm's transparency and public recognition, and the lender's special knowledge and expertise regarding the firm. Financial institutions staffed by competent and experienced auditing officers and equipped with the appropriate rating program can audit any firm more efficiently than those not so prepared. Any lender, regardless of its monitoring efficiency, can audit more transparent and more publicly known firms with greater ease than it can more opaque and less publicly recognized ones. Lenders who specialize in specific industries or those who have special relationships with certain borrowing firms and have access to hard to obtain information take advantage of overseeing such industries and firms more efficiently than other lenders.

Since the higher lending rate has two opposing effects on the lender's expected profit, a higher return upon the firm's success and an increased likelihood of the borrower firm's default, the lender's expected profit does not necessarily increase monotonically in the lending rate. Thus, the profit maximizing lender does not intend to increase lending supply monotonically in the rate, either. If the lending demand is sufficienly high, the supply and demand curves do not necessarily intersect, thus, results in the Williamson

\footnotetext{
${ }^{2}$ The model assumes that the return of the firm's project is the private information to the firm without the lender's monitoring. Unless the lender exercises costly ex-post monitoring, upon the borrower's default, he cannot know whether the borrower firm cheats the lender when the invested project is indeed successful or he truthfully reports that the project fails.
} 
(1987)'s equlibrium credit rationing. ${ }^{3}$

\subsection{Small Business Finance and Trade Credit}

Before further developing the discussion on the theoretical background, we shift our focus briefly to the reality of small business finance. The major sources of external finance by small firms are institutional lenders, mostly socalled relationship lenders, and trade credit, a medium of short term credit. 4 Trade credit is the major alternative to institutional borrowing for small firms that are restricted access to unmonitored bond financing. The data in the 1998 SSBF show that 66 percent of small firms that employ less than 500 people use trade credit and on average 43 percent of the total credit owed by the firms is trade credit. ${ }^{5}$ Indeed both figures exceed the corresponding figures on relationship lending (44 percent and 37 percent).

Trade credit is a type of lending contract made between non-financial firms. The supplier firm of goods and services allows the buyer to defer the payment. The lag between the date of delivery of goods or services rendered and the date of payment means that the credit is granted by the supplier firm to the buyer firm. Unlike the simple lending contract the trade credit contract is fairly complex.

The representastive contract has four components: the discount rate, the discount due date, the net due date, and the penalty rate. These four components are set up so that the buyer is given an incentive to repay at the earlier time. The buyer firm is offered a one to two percent discount on sold goods if it pays within a shorter period of time. Thus missing the discount due date would require the buyer an expensive opportunity cost. ${ }^{6}$ Further

\footnotetext{
${ }^{3}$ Williamson (1987) obtains the interesting case of the backward bending lending supply curve with a unique maximum of supply of loans. This ensures the equilibrium credit rationing with a sufficiently high lending demand.

${ }^{4}$ Neither equity finance nor bond finance is visible presumably because of the small amount of external funds needed. Bolton and Freixas (2000a, 2000b) argue that the only option available to the riskiest start-ups is equity finance. It appears that such firms in the 1998 Survey of Small Business Finances (SSBF) do not issue equity publicly but either the owner, his family, or his acquaintances provide additional equity if it is needed.

${ }^{5} \mathrm{~A}$ detailed description of the SSBF survey and the descriptive statistics on the survey data will appear in section 4.

${ }^{6}$ Under the typical contract with 10 days as the discount due date, 2 percent as the discount rate, and 30 days as the net due date, missing the discount due date would require the buyer to pay an annual 43.9 percent of opportunity cost, what we call the implicit
} 
down the road, if the buyer fails to pay by a certain date called the net due date, a penalty rate is imposed on the buyer. However, if as the buyer firm makes its remittance by the discount due date, the credit is cost free. A typical contruct structure is depicted in Figure $1 .{ }^{7}$

\subsection{Specialist and Non-specialist Intermediaries}

Unlike the conventional empirical works that intend to examine advantages of relationship lenders over non-relationship lenders, our empirical interest is in the relative advantage of the specialist financial intermediary, who is engaged solely in financial business, over the non-specialist, who is engaged in both financial and non-financial activities. ${ }^{8}$ Bond (2003) discusses that the specialist emerges when the total aggregate monitoring costs in the economy are reduced with the intermediary rather than without. According to his discussion trade credit is a more efficient form of financial intermediation than institutional lending, all other things being equal. Since the nonspecialist intermediary does not have to monitor itself, intermediation by the non-specialist reduces the aggregate costs of monitoring in comparison to the intermediation by the specialist.

Figure 2 depicts the specialist intermediation and the non-specialist intermediation in a simple environment with only two borrowing firms (entrepreneurs). The non-specialist intermediary has to monitor only one firm whereas the specialist intermediary has to monitor and verify both entrepreneurs, and hence the total (aggregate) monitoring costs are higher with the non-specialist intermediary if the unit monitoring cost is the same for both the specialist and the non-specialist. Therefore the specialist intermediary emerges only when it is substantially more advanced in monitoring borrowers

interest rate.

The implicit interest rate $r^{i}$ is calculated according to the following formula.

$$
r^{i}=\left(\frac{100}{100-r^{d}}\right)^{\frac{360}{N E T-D I S}}-1
$$

where $r^{d}$ is the discount rate, NET is the number of days from the date of derivery to the net due date, and $D I S$ is the number of days to the net due date.

${ }^{7}$ For the detailed discussion on trade credit contract, see Ng, Smith, and Smith (1999).

${ }^{8}$ The supplier - buyer relationship can be as long lasting and strong as the lender borrower relationship. So many of supplier firms providing trade credits can be also relationship lenders. The literature review will appear in section 2.5. 
than the non-specialist.

\subsection{Monitoring Technology and Transparency}

It is the commonly held conventional wisdom that the advanced monitoring technology of the specialist lender allows it to audit opaque firms with obscure accounting and management records as easily as it can transparent firms with higher quality of written records. ${ }^{9}$ A specialist lender equipped with better monitoring capability is able to offer funds to a viable firm whose written documents on accounting and management are poorly recorded more cheaply than a non-specialist. For instance, the advanced monitor has informal access through its close contacts with the manager to information that is not recorded in either the hard copy or electronic files. Unlike recorded hard information such soft information is hard to obtain without expertise and special knowledge.

However, the opposite sechario is also easily justifiable. The efficient lender could be good at processing and analyzing the recorded information rather than extracting the soft information through informal activities. ${ }^{10}$ Therefore a specialist lender offers cheaper funds to firms with better management and accounting records. On the other hand, a non-specialist lender is indifferent to firms regardless of availability of information on them, since the recorded information, which would be useful for the advanced auditor to judge the firm's solvency and viability, and to verify the firm's default, is nothing but a blank paper. Therefore the superior auditor charges a higher interest premium against opaque firms, whereas the inferior auditor provides funds to them at the same cost as the funds to more transparent borrowers.

In reality both cases must coexist. It is, therefore, an empirical question as to which case is more of relative importance. If the former dominates the latter, we observe that the more transparent small firm chooses institutional lending (a specialist) over trade credit (a non-specialist), and vice versa.

\footnotetext{
${ }^{9}$ This point is particularly made in the relationship lending literature. For the relationship lending theory, see Diamond and Rajan (2000, 2001) and Kashyap, Rajan and Stein (2002).

${ }^{10}$ For instance Petersen and Rajan (2002) discuss that the historically observed widening distance of the (specialist) lender and the borrower is likely to reflect the fact that detailed hard information is easily obtainable electronically thanks to the rapid development of information technology.
} 


\subsection{Empirical Literature}

There are relatively few empirical works that attempt to relate the firms' financial decisions or the cost of lending directly to their informational characteristics. Based on the Duffie and Lando (2002) model of the credit spreads of bonds issued by firms with imperfect accounting and using the percentile ranking of the firm's transparency of accounting information calculated from the data published by the Association for Investment and Management Research, Yu (2002) finds that the spread attributable to the extent of the bond issuing firms' accounting imperfection is positive and statistically significant.

The closely related work attempting to examine the influence of the firm's informational characteristics on the cost of borrowing is Petersen and Rajan (2002). Interpreting that the geographical closeness to the borrower firm implies better monitoring, with 1987 and 1993 SSBF surveys, they estimate the effect of the distance predicted by the firm's informational characteristics on the probability that the institutional lender accepts the application and the contractual lending rate, and find that the effect has become less important. They discuss that the ease with which the lender can now acquire the borrower information through the development of information technology does not require the direct contact that the physical closeness allowed in the past. Using Argentine data on banks and small firms Berger, Klapper, and Udell (2001) find that large foreign owned firms, whose decisions on lending are likely to be made at their headquarters physically far from the small firms, are more inclined to supply loans to small firms in a period of financial distress than would small domestic banks. With 1987 SSBF data Petersen and Rajan (1994) find that an older firm is charged the lower interest rate on the most recently accepted loan. As a related area of study there are a relatively large number of works examining the role of the relationship in small business finance. ${ }^{11}$

\footnotetext{
${ }^{11}$ With 1987 data Petersen and Rajan (1994) find that the length of the relatiionship does not have significant negative effect on the interest rate charged on the most recently accepted loans, whereas Berger and Udell (1995) with the same data find the negative effect of the length of relationship on the premium over prime rate for loans issued under lines of credit. With 1993 data Cole (1998) examines the effect of pre-existing relationships such as the firm's possession of deposit accounts and the length of relationship on the lender institution's probability to extend the existing contract and find the significant effect of relationship variables. Degryse and Cayseele (1999) using the large Belgian contract level data on bank lending to small firms find that the length of relationship and the main bank reduces the contractual lending rate. Hoshi, Kashyap, and Scharfstein (1991) find that
} 
Petersen and Rajan (1997) extrapolate from 1987 SSBF data that the demand for trade credit measured by the accounts payable over assets increases with the firm's age, and decreases in the length of a relationship with a financial institution, suggesting that an older firm uses less institutional lending and replaces its financial needs with trade credit. With the same data Petersen and Rajan (1994) find that the use of trade credit measured by the percentage of trade credits that were paid after the due date and the negative of discounts taken by the borrowing firm decreases as firms age and is higher for a corporation. However, to the best of our knowledge there is not a single paper that directly examines the role of informational characteristics on the small firm's choice of external credit from trade credit and institutional lending, two of equally important financial sources for small firms.

\section{Data and Empirical Methodology}

\subsection{Data Description}

The Survey of Small Business Finances (SSBF) is conducted by the Board of Governors of the Federal Reserve System and collects information on forprofit, non-financial, non-farm, non-subsidiary business enterprises in the United States that have fewer than 500 employees. The information collected includes the firm's legal origin, various owner characteristics such as age, education, management experience, ownership concentration, the firm's geographical expansion, firm age, use of financial services, the firm's relationships with financial institutions, and the firm's income and balance sheets. The SSBF has provided the most reliable data set on the management and financial information of small firms, and is widely used by economics and finance researchers. ${ }^{12}$

The 1998 survey is the third in a series of surveys along with the 1987 and 1993 surveys. Reflecting the development of information technology in the late 1990s, the 1998 survey collects data on the firm's use of computers

the Japanese firms in a keiretsu corporate group, who are expected to have close ties to the main bank in the group, are more insulated from liquidity shocks in their investments than firms not affiliated with a keiretsu.

${ }^{12}$ The complete set of works that use the SSBF are available on the web page of the Federal Reserve Board of Governors at http://www.federalreserve.gov/pubs/oss/oss3/abstract.html. 
for business purposes. This allows us to construct the more appropriate variable that captures how well hard information on the firm's accounting and management is recorded. Previous surveys have asked the firm what types of written records the firm uses, if there are any in answering the survey. Such information may serve as a proxy for the state of maintenance of information, but it is not a direct measure. It may be that the firm with very good written records simply did not have the records within the respondent's reach. In this case, use of written records does not have economic meaning on the firm's business operation. The number of firms surveyed was 3,561, an adequately large sample size to conduct the statistical analysis.

\subsection{Econometric Model}

We model the small firm's external financial demand as the firm's discrete choice of financial sources. The survey questionnaires of the SSBF include not only the firm's current balances of items in liabilities but, more importantly, the firm's recent applications for these. The advantage of using data on applications rather than post contract data is that one can identify the firm's demand from a certain financial source no matter if the application from such a source is granted or not. Firms unsuccessful in their credit applications have a credit demand but do not show it as a liability on their own balance sheets.

We assume that the small firm decides whether to apply to institutional lending or not and whether to apply to trade credit or not. ${ }^{13}$ Under this assumption there are four states in one of which any given firm falls: no demand for trade credit or of institutional lending (no demand of external credit); only trade credit; only institutional lending; and both trade credit and institutional lending. Each firm chooses one of these financing alternatives depending on its informational and demographic characteristics. We employ probabilistic choice models discussed in Amemiya (1985) to characterize the firm's choice. More precisely, we estimate the following conditional probability that the firm $i$ chooses a financial source (mix) $j$.

$$
P_{i j}=\operatorname{Pr}\left(d_{i}=j \mid x_{i}\right), j=0,1,2, \text { and } 3
$$

$d_{i}$ is the dichotomous variable that takes on values 1 if the firm $i$ has no

\footnotetext{
${ }^{13}$ Other alternatives for external finance by small firms are almost non-existent in the data.
} 
external credit demand, 2 if it applies to only trade credit, 3 if it applies to only institutional lending, and 4 if it applies to both trade credit and institutional lending. One widely used functional form for the conditional expectation $P_{i j}$ is the logit family. Its mathematical simplicity allows us to estimate the model parameters relatively easily. The models can be derived from the optimal choice of the source of external credits by the firm. Denoting $U_{i j}$ as the firm $i$ 's utility from choosing the financial source $j$ and $J=\{0,1,2,3\}$ we get,

$$
P_{i j}=\operatorname{Pr}\left(U_{i j}>U_{i k}, \forall k \in J \backslash j \mid x_{i}\right), j=0,1,2 \text {, and } 3
$$

We further assume that $U_{i j}=x_{i} \beta_{j}^{*}+\varepsilon_{i j}$ so that the firm's utility is composed of a deterministic part attributable to the firm $j$ 's various characteristics and the stochastic disturbance. We assume that there are $K$ variables that capture the firm's characteristics so that $x_{i}$ is a $1 \times k$ column vector. The logit family specifies the (joint) distribution function of $\varepsilon_{i j}$ to be (the function of) the extreme value function given by $\exp \left[-\exp \left(-\varepsilon_{i j}\right)\right]$.

We examine three specifications of the logit model family: the multinomial logit model; the nested logit model; and the nested multinomial logit model. Their differences are based on assumptions made on the structure of the decision making. It is likely the case that only firms in need of external credits proceed to the decision of choosing one of the three alternative external credit sources. That is, the firm must decide at first whether or not to apply for external credits at all regardless of any specific source, and then choose only trade credit, only institutional lending, or both of them. The three specifications differ in the way they deal with such a structure of the decision making process. ${ }^{14}$

Multinomial logit model

The multinomial logit model does not take into account the firm's twostage sequential decision. The first figure of Figure 3 shows the firm's decision tree assumed by the multinomial logit model. The firm chooses one of all four alternatives simultaneously. The model then assumes the independence of stochastic disturbance $\varepsilon_{i j}$ across any alternative $j$.

One can derive the probability that firm $i$ chooses an alternative $j$ as the function of indices $x_{i} \beta_{l}$ 's as,

\footnotetext{
${ }^{14}$ For a formal derivation of models, see Amemiya (1985).
} 


$$
P_{j i}=\frac{\exp \left(x_{i} \beta_{j}\right)}{1+\sum_{l=1}^{3} \exp \left(x_{i} \beta_{l}\right)}, j=0,1,2, \text { and } 3, \beta_{0}=0
$$

Note that one cannot identify all parameter vectors for four different states. We can only identify the difference of the parameter vector for the comparison group $\left(\beta_{0}^{*}\right)$ and each of the remaining three $\beta_{j}=\beta_{j}^{*}-\beta_{0}^{*}$.

Nested multinomial logit model

The nested multinomial model is the special case in which the two-stage nature of the firm's decision making process is explicitly imposed as a structure. The firm decides whether to borrow or not regardless of the source of external credits at the first stage. Firms that decide not to borrow are not allowed to choose the specific source of credits. Only firms that decide to borrow are. The decision tree for the nested multinomial logit model is portrayed in the second figure of Figure 3. One can write the (unconditional) probability of not borrowing and and the conditional probability of choosing the source $j$ respectively with parameters $\beta$ and $\gamma_{j}$ 's as,

$$
\begin{gathered}
P_{0 i}=\operatorname{Pr}\left(d_{i}=0\right)=\frac{1}{1+\exp \left(x_{i} \beta\right)} \\
\operatorname{Pr}\left(d_{i}=j \mid d_{i} \neq 0\right)=\frac{\exp \left(x_{i} \gamma_{j}\right)}{1+\sum_{l=1}^{2} \exp \left(x_{i} \gamma_{l}\right)}
\end{gathered}
$$

15

Nested logit model

The nested logit model is the most general model of the three and the abovementioned nested multinomial logit and multinomial logit models are special cases of the nested logit model. ${ }^{16}$ The nested logit model relaxes the strict independece property of the multinomial logit model and allows correlation among the firm's utilities from different sources of external credits.

\footnotetext{
${ }^{15}$ Note, $\operatorname{Pr}\left(d_{i}=j\right)=\operatorname{Pr}\left(d_{i}=j \mid d_{i} \neq 0\right) \operatorname{Pr}\left(d_{i} \neq 0\right)=\frac{\exp \left(x_{i} \beta\right)}{1+\exp \left(x_{i} \beta\right)} \frac{\exp \left(x_{i} \gamma_{j}\right)}{1+\sum_{l=1}^{2} \exp \left(x_{i} \gamma_{l}\right)}$
}

${ }^{16}$ Strictly speaking the nested multinomial logit model is not the special case of the nested logit model. However, the multinomial logit part at the second stage can be obtained as the special case of the conditional probabilities in the nested logit model as it will be evident. 
The decision tree for the nested logit model is depicted in the last figure of Figure 3.

One obtains the unconditional probability that the firm $i$ does not apply to any of external credits $P_{i 0}$ and the probability of choosing an external credit source $j$ conditional on that the firm $i$ does apply to one of three external credit sources respectively as,

$$
\begin{gathered}
P_{0 i}=\frac{1}{1+a\left\{\sum_{l=1}^{3} \exp \left(\rho^{-1} x_{i} \beta_{l}\right)\right\}^{\rho}} \\
P_{2 j i}=\operatorname{Pr}\left(d_{i}=j \mid d_{i} \neq 0\right)=\frac{\exp \left(\rho^{-1} x_{i} \beta_{j}\right)}{\sum_{l=1}^{3} \exp \left(\rho^{-1} x_{i}^{\prime} \beta_{l}\right)}, j=1,2, \text { and } 3
\end{gathered}
$$

where the subscript 2 represents the second stage, and $\rho$ and $a$ are model parameters. In particular, $\rho$ is the correlation parameter. 17

Marginal effects

We estimate these models by the maximum likelihood estimation. Indeed, in non-linear discrete choice models including the logit family, coefficient vectors themselves are of little interest to us unlike in linear models in which coefficients themselves are marginal effects of changes in independent variables on the dependent variable. We are interested in either levels of the unconditional and second stage conditional probabilities per se for a certain value for a vector of characteristics variables $x_{i}$ or the effect of marginal change in a certain variable in the vector $x_{i}$ on the probabilities (the marginal effect).

The marginal effect on the unconditional probability is given by $\frac{\partial \operatorname{Pr}\left(d_{i}=j\right)}{\partial x_{m i}}$ for a continuous variable $x_{m}$. The marginal effect for a binary (dummy) variable $x_{m^{\prime}}$ given by $\left.\operatorname{Pr}\left(d_{i}=j\right)\right|_{x_{m^{\prime} i}=1}-\left.\operatorname{Pr}\left(d_{i}=j\right)\right|_{x_{m^{\prime} i}=0}$, represents the associated change in the probability with a change of the $m^{\prime}$ th variable from 0 to 1 . The marginal effects for the conditional probability are analogous. Since these marginal effects are the functions of $x_{i}$, one needs to compute the

\footnotetext{
${ }^{17}$ The unconditional probability of choosing an alternative $j(\neq 0)$ can be obtained by $P_{j i}=\operatorname{Pr}\left(d_{i} \neq 0\right)$

$\operatorname{Pr}\left(d_{i}=j \mid d_{i} \neq 0\right)=\left(1-P_{0 i}\right) P_{2 j i}$. The formula degenerates to the formula for the multinomial logit model (??) if $\rho=a=1$. $\beta_{1}=0$ and $\rho=1$ in (4) result in the formula for the second stage multinomial logit model in the nested multinomial logit model, (2).
} 
sample average to evaluate the effects numerically. In calculating the effect of each single variable for each observation, which is then used for averaging over all the observations, other variables are kept at the original value of the observation. ${ }^{18} 19$

\subsection{Variables}

Dependent variable

Regarding institutional lending, the SSBF asks not only how many times the firm applied for new loans but also if there were times when the firm needed credit but did not apply because it thought the application would be turned down. The firm that did not apply for loans for fear of being rejected by the institution can be interpreted to have had demand for loans. As our objective is to construct the variable that represents the firm's demand for loans, we should include both actual applications and voluntary withdrawals. ${ }^{20}$ Table 1 shows the descriptive statistics on the variables used to construct the dependent variable and the dependent variable itself.

It appears that quite a few firms withdrew voluntarily from applying for a loan (22 percent) and a majority of them (63 percent) never applied for a loan afterward. Among the firms that applied for the loan afterward, 60 percent of them were never successful in any of their applications. Thus only 15 percent of firms that had ever withdrawn from application fearing rejection were indeed accepted by some lenders in the end. Among firms that had applied for a loan at least once, most of them (83 percent) obtained loans eventually and half of the firms who were successful at least once stopped submitting applications with their first successful application. Roughly speaking, there are two model groups within firms demanding institutional lending. The first group of firms do not even attempt applying for a loan and withdraw voluntarily in the last three years. The second group searches around for lenders until they are successful, then stop shopping. The mode of the

\footnotetext{
${ }^{18}$ As each probability is a non-linear function of $x_{i} \beta_{l}$ 's, the marginal effect for each variable is not a function of only a coefficient for the variable of interest itself but a function of all parameters including parameters for other alternatives and other model parameters if they are modeled so. Thus neither the statistical significance nor the insignificance at any given significance level of a coefficient in the linear index of the model $x_{i} \beta_{l}$ does not say much about the statistical significance of the marginal effect.

${ }^{19}$ In estimating standard errors of marginal effects, the standard delta method is used.

${ }^{20}$ Petersen and Rajan (2002) employ the same approach to define firms that were rejected loan applications.
} 
number of demands for institutional lending within a three-year period is $1 . .^{21}$

Regarding trade credit, the SSBF asks both use of trade credit and experiences of rejection of trade credit by a supplier firm in the last one year period. Two thirds of firms used trade credit, whereas only 1 percent of firms had been denied and never had trade credit in the one year period. ${ }^{22}$

We construct the dependent variable by combining the data on the application to institutional lending and on use of trade credit and arranges firms into four groups, firms without demand for external credits (21 percent), firms demanding only trade credit (38 percent), firms demanding only institutional lending (11 percent), and firms demanding both trade credit and institutional lending (30 percent).

Though the period of time during which institutional lending is surveyed is much longer (three years) than that for trade credit (one year), combining both sets of data does not cause serious problems since firms are almost split between those using trade credit and those not using it, and this division among firms seems to be a steady state phenomenon. Firms that used trade credit in the survey year are very likely to have used trade credit in the previous two years, too, whereas those that did not in the year are not very likely to have stopped use of trade credit all of a sudden after two years of trade credit use. This is a reasonable assumption also because use of trade credit is a high frequency event and not an event which takes place only once or twice in three years. Indeed firms that use trade credit on average used trade credit for 72 percent of all purchases they made.

Independent variables

Table 2 shows the descriptive statistics of independent variables that are meant to measure the firm's informational characteristics.

RECORD is a dummy variable which takes a value of 1 if the respondent used some kind of written records to answer the survey questionnaires and 0

\footnotetext{
${ }^{21}$ The SSBF investigates the decomposition of institutions to determine which firms made their most recent approved and denied applications separately. 91.8 percent of approved and 88.4 percent of denied applications were made to depository institutions. This means that in analyzing the sample of small firms institutional lending and bank lending are almost synonymous. The decomposition of institutional lenders to which firms withdraw without an actual attempt is not available in the survey, but it appears reasonable to assume that such firms consider applying mostly to banks as well.

${ }^{22}$ The low rejection rate of applied trade credit suggests that it is unlikely that large number of firms withdraw applying to credit voluntarily.
} 
if he/she relied on his/her memory. If the firm keeps the written records in an organized manner, they must be readily available to the firm's manager (respondent). Well organized records must also be more informative to outside lenders. Seventy nine percent of firms used some kind of written records. ${ }^{23}$

PCFMAN is a dummy variable which takes a value of 1 if the firm uses computers for its accounting. Use of computers for accounting would leave more accurate records of the firm's accounting information. As we described earlier, this variable is new in the 1998 data and our primary interest in estimating discrete choice models. Seventy percent of firms use computers for accounting.

RECORD and PCFMAN are meant to be direct measures of availability of hard information to lenders. Besides, two additional variables are included as indirect proxies. They are dummy variables indicating whether the firm is managed by an owner (OWNER) or whether it is a corporation (CORP). A firm managed by a hired manager is more likely to leave better detailed and informative hard information for communications between the owner and the manager. Corporations are required to have higher standard of accounting records.

The dummy variable indicating whether its sales region stretches nation wide (NATIONAL) is also included. In addition such continuous variables as the number of branches (BRANCH), owner experience (C_EXP), owner age (C_OAGE) and firm's age (C_FAGE) are included as independent variables. They are all meant to measure the firm's transparency and public recognition. The geographical expansion of the firm, an older owner with longer experience, and a longer firm history all tend to make the firm more recognized by the general public. ${ }^{24}$

Demographic variables such as the industry, the geographic location, and the ethnic origin are included to control the firm's other fixed characteristics. A complete set of independent variables and their explanations are listed in Table 3 .

\footnotetext{
${ }^{23}$ It may be the case that the respondent simply did not use the written records to answer the survey although it has the informative written records. If this is true for large number of firms that did not use written records, RECORD may have little economic meaning.

${ }^{24} \mathrm{CORP}$ captures the firm's transparency besides availability of written records since corporations are required to maintain a higher standard of disclosure.
} 


\section{Results}

\subsection{Estimation results}

Comparison of models and parameter estimates

In conducting the empirical analysis firms whose answers on questionnaires concerning recent loan applications and trade credit applications were questionable are dropped. Firms that report holding zero gross assets are not likely to be reflecting their true balance sheets, and therefore, are dropped. 3477 firms remain in the sample.

Table 4 shows the parameter estimates and the maximized log likelihoods of three estimated models. The nested logit model is superior to the other two in terms of the likelihood principle. Table 5 shows the marginal effects of variables on the conditional probabilities of choosing a source of external credit for three models. Both point estimates and standard errors appear to be independent of the choice of a model. These suggest that our further discussion be based on the results of the most general nested logit model. Many of the coefficients for variables that are meant to capture the availability of the firm's information and its transparency are estimated relatively accurately. Among 27 coefficients that represent the first nine elements of coefficient vectors for three choices of external credit source, 13 are statistically significant. In particular, coefficients on CORP and BRANCH are significant across all the alternatives. ${ }^{25}$ These findings support the choice of variables for the empirical model. ${ }^{26} 27$

Table 5 presents the marginal effects of individual variables on the firm's unconditional probabilities of financial choices and conditional probabilities of choices of external credits (Panel A). In order to show that results are

\footnotetext{
${ }^{25}$ Dummy variables PCFMAN and RECORD are only two variables that measure the secular informational characteristics.

${ }^{26}$ Some of such variables may capture not only the informational characteristics but other effects. For instance the firm's legal status and branching may capture its endogenous management strategy rather than fixed effect characteristics.

${ }^{27}$ The point estimate of the correlation parameter $\rho$ is negative and statistically significant. It is hard to interpret the negative estimate of $\rho$ since it normally takes the value in the range from 0 (perfect correlation) to 1 (no correlation, multinomial logit). The negative $\rho$, however, is not ruled out in the econometric theory. The estimate of $\rho$ may not be so reliable. Indeed the estimate of the model which assumes $\alpha=1$ but keeps $\rho$ as a free parameter results in the positive and statistically insignificant $\rho$. We find that results on estimated probabilities and marginal effects are robust to such model assumptions.
} 
robust across the models, marginal effects on conditional probabilities computed with multinomial logit and nested multinomial logit models are attached (Panel B). Table 6 presents the average, taken from observations, of levels of unconditional probabilities for each financial choice (Panel A) and conditional probabilities for each choice of external credit source (Panel B) when each dummy variable indicated as the title of column entries is held constant either at 0 or at 1 across observations, and other variables are kept at the original observed values. ${ }^{28}$ The rest of this subsection presents our empirical findings in Tables 5 and 6 and supplemental figures for continuous variables.

Availability of the firm's hard information

As we will detail below, our empirical findings on the relationship between the availability of the recorded information on small firms and their credit demand are summarized in three main points. First, these firms whose accounting and management information are thought to be better kept are more likely to seek some form of external credit than those firms whose information is poorly recorded. Second, firms with poor written records start with institutional borrowing, and add trade credit as their second choice of financing as their records become better organized. Third, the empirical results from the dummy variable PCFMAN shows the clearest evidences, whereas the results from other variables are supportive of the findings from PCFMAN.

Direct measures (PCFMAN, RECORD)

The probability that firms using computers for accounting (firms with PCFMAN=1) apply for some external credit is 82.3 percent, whereas the probability that firms without computer assistance (PCFMAN=0) apply to it is only 72.1 percent. That is, use of computers for accounting increases the firm's demand of external credit by 10.2 percentage points. ${ }^{29}$ Such firms are 4.3 percent more likely to choose trade credit only (34.8 percent for the firms not using computers for accounting as opposed to 39.1 percent for firms without them. For any dummy (binary) variable to be mentioned,

\footnotetext{
${ }^{28}$ For each dummy variable, a number in one of the cells in Table 5 is equal to a number in the corresponding cell in the second panel (a dummy variable is held at 1) of Table 6 less a number in the corresponding cell in the first panel (a dummy variable is held at 0 ) of Table 6 .

${ }^{29}$ Note that reported figures for marginal effects are point estimates. They accompany standard errors. Thus these figures are merely expectations (averages) over randomization based on the empirical distribution of model parameters and not deterministic.
} 
the first percentage is the probability of each choice for the less transparent firm and the second one is that for the more transparent firm implied by the variable, unless noted otherwise), 9.0 percentage points more likely (23.9 percent, 32.9 percent) to apply to both lending and trade credit, and 3.1 percentage points less likely (13.3 percent, 10.3 percent) to choose lending only. All of these effects on unconditional probabilities are statistically significant. As a result, introduction of computers for managing accounting raises the unconditional likelihood of applying to trade credit, combining the likelihoods of the exclusive choice of trade credit and the choice accompanying institutional lending, by 13.3 percentage points. On the other hand, it raises the likelihood of applying for institutional lending only by 5.9 percentage points.

Looking at the marginal effects on the conditional probabilities of choosing from the options of credit sources, the shift from institutional borrowing to trade credit is indeed the shift from demand of institutional lending to demand of trade credit besides lending. Firms that make more information available if requested (by creditors) tend to prefer the mix of trade credit and institutional borrowing over dependence on institutional borrowing. On the other hand, firms that do not record solid information are more likely to be dependent on institutional borrowing.

Conditional on the firm's need of external credit, the probability that the firm applies only to lending falls by 7.0 percentage points (20.0 percent,13.0 percent) and the probability that it applies both to lending and trade credit rises by 7.2 percentage points (32.1 percent, 39.3 percent). Both effects are statistically significant at the 1 percent level. Two effects almost cancel each other out and leave little room for the likelihood change of applying for trade credit only. ${ }^{30}$ The total likelihood of choosing trade credit (the conditional probability of either choosing trade credit only or of choosing trade credit besides institutional borrowing) increases by 7.0 percentage points as the firm introduces computers for accounting ( 80.0 percent, 87.0 percent). In contrast, the total probability to choose lending barely increases (52.0 percent, 52.3 percent).

The findings on the influence of RECORD on the firm's financing requests are consistent with the findings for PCFMAN. On average, firms using written records to answer the survey are more likely to apply to exter-

\footnotetext{
${ }^{30}$ Marginal effects for alternatives are summed up to 0 since corresponding probabilities are summed up to 1.
} 
nal credit than firms answering the survey without them, and are more likely to apply for both institutional lending and trade credit. The marginal effect on the unconditional probability that the firm applies to lending only and the effect on the probability that it applies to trade credit only is negligible. Regarding the chances that firms in need of credit choose one of the three alternatives, firms answering the survey with some kind of written records are less likely to choose lending only and more likely to choose the mix of lending and trade credit. None of the reported marginal effects, however, are statistically significant at the 10 percent significance level.

\section{Indirect measures}

Firms managed by an employee $(\mathrm{OWNER}=0)$ are 4.7 percentage points more likely to apply for external credit than owner managed firms (78.5 percent, 83.1 percent) and the effect is statistically significant. Employee managed firms are more likely to apply for trade credit only, more likely to apply for both trade credit and lending, and less likely to apply for lending only. However, none of these effects is statistically significant at the 10 percent level. The unconditional probability of applying to trade credit rises by 8.0 percent (74.9 percent, 67.0 percent) as the owner managed firm hands its management over to a hired manager. As for the conditional probabilities of the choice of a financial source, the owner managed firm is 5.4 percentage points more likely to choose lending only than the employee managed firm by 5.4 percent (15.7 percent, 10.4 percent, significant at the 10 percent significance level) and is less likely to choose the other two alternatives. The marginal effect on the conditional probability of choosing the mix of lending and trade credit is more than twice as great as that of choosing trade credit only (marginal effects for these are not statistically significant). These findings are supportive of findings from PCFMAN and RECORD.

Corporations $(\mathrm{CORP}=1)$ are 7.1 percentage points more likely to apply for some external credit than non-corporations (15.5 percent, 22.6 percent), and 5.1 percent points more likely to apply to both trade credit and institutional lending (29.0 percent, 34.1 percent). These effects are statistically significant. The unconditional likelihood that the corporation chooses trade credit only is higher than the likelihood that a non-corporation chooses one, but the difference in likelihoods between two types of firms, 2,9 percent, is small and not significant. The (unconditional) marginal effect on the choice of lending only is insignificant but negative. As for the marginal effects on the conditional probabilities of choosing an external credit source, a corporation is more likely to choose the mix of lending and trade credit and less 
likely to choose lending only than a non-corporation Neither of the marginal effects on the conditional likelihoods of choosing these two is significant but point estimates of two are almost equal in absolute value at around three percent. The conditional likelihood of choosing trade credit only, when the firm needs credit, does not differ across different types of legal entities.

The firm's public recognition

The findings on how the number of branches affects the firm's financing decision, which will be presented in details, are consistent with the findings on the influence of availability of the firm's hard information on its financial decision. More branches encourage the firm to attempt to give up selfreliance and to seek some kinds of external line of credit. Firms tend to seek trade credit besides institutional lending as the number of business sites grows. On the other hand, older firms, firms owned by more experienced or older owners, are not necessary more likely to seek credits than otherwise. Such time factors tend to induce firms to shift from lending only to trade credit only rather than to mix both types of borrowing. These variables are indirect proxies to the firm's public recognition. One would need to ask all lender institutions and trade credit providing firms whether and to what extent they know each surveyed firm if he were to collect the direct information.

Marginal effects of the increased number of branches on unconditional probabilities are negative and significant for a choice of no application to any external credit, and positive and significant for choices of trade credit only and the mix of trade credit and lending. Marginal effects on probabilities of the firm's conditional choice are less obvious. The only conditional choice on which the marginal effect of marginal increase in the number of branches is statistically significant is a positive effect on the choice of the mix of lending and trade credit. The marginal effect on the conditional probability of choosing lending only is negative but not significant. The effect for the choice of trade credit only is negligible. Figure 4 shows changes of the decomposition of unconditional (top figure) and conditional (bottom figure) probabilities across available choices associated with increase in the number of branches. Very few firms (1,9 percent) at the top 99 percentile of number of branches which have at least 11 branches are estimated to refrain from the external credit voluntarily, whereas nearly half of them (44.0 percent) are estimated to apply both for trade credit and to lending institutions. In contrast, the corresponding figures are 22.5 percent and 29.2 percent for firms with only one site of business who are the dominant majority (79 percent) 
in the sample. As the number of branches increases, dependence on internal funds vanishes and is replaced by demand of the mix of trade credit and institutional lending. 31

Marginal effects of operating nation wide as opposed to operating locally on both conditional and unconditional probabilities are positive for lending only and negative for trade credit only. These effects, however, are not significant. The findings with NATIONAL contradict the findings with indicators of availability of the firm's hard information. A possible explanation for this is that the variable NATIONAL captures the geographical network of lenders. While financial lending institutions represented by banks have relatively large geographical networks and are able to satisfy the financial needs of firms expanding their sales channels nationwide, supplier firms providing trade credit to small firms, whose trade partners, many of whom are also likely to be small firms with small numbers of business sites, are less likely to match their financial needs.

Figure 5 shows the estimated relationship between the owner experience and the firm's financial choice. The first figure on the unconditional probabilities implies that the more experienced owner demands external credit (the relationship is not statistically significant). Figures on the unconditional and conditional probabilities consistently show that the more experienced owner is more likely to choose trade credit only and less likely to choose lending only. The likelihood that the least experienced owner (in the first year of his business career) is dependent solely on institutional lending is substantial (21.2 percent). On the other hand, for instance, the owner's thirty-year experience in the small business reduces the likelihood by almost half (11.4 percent of the likelihood). The decline in bank dependence is almost replaced by the rise in dependence on trade credit. The likelihood that the firms become solely dependent on trade credit rises substantially with a thirty years of business experience (42.8 percent to 50.6 percent). ${ }^{32}$

Figure 6 shows the estimated relationship between the firm's age and the firm's financial choice. The firm's age is irrelevant to the firm's decision

\footnotetext{
${ }^{31}$ Indeed the unconditional probability of applying only for trade credit keeps increasing in the number of branches until it reaches11, and then starts to decrease. Ninety nine percent of firms, however, have less than 12 branches. The negative relationship does not alter the course of the discussion.

${ }^{32}$ Owners with 30 year experience of doing business are at the top 86.3 percentile of the sample. The median of owner experience is 18 years. Thirty year old firms are at the top 91.4 percentile and the median firm age is 11 years.
} 
to seek external credit per se. The marginal effect of the firm age on the unconditional probability of being self reliant for its financing is negligible. As for the firm's choice of credit source, younger firms are more likely to choose institutional lending and older firms are more likely to be dependent on trade credit. For instance thirty-years of staying in business increases the likelihood that the firm chooses trade credit only from 40.9 percent to 55.1 percent, reduces the likelihood that it chooses lending only from 17.6 percent to 12.0 percent and the likelihood that it chooses the mix of lending and trade credit from 41.4 percent to 32.9 percent

Figure 7 shows the relationship between the owner age and the firm's financial choice. Unconditionally the firm is more likely to withdraw from external credit and less likely to apply to lending institutions as the owner ages. The marginal effect of the owner's age on unconditional probabilities not to apply for any external credit is positive and significant. ${ }^{33}$ The marginal effects on unconditional probabilities of choosing lending only and the mix of lending and trade credit are negative and statistically significant. The likelihoods that a forty year old owner chooses to be self-reliant, chooses lending only, lending and trade credit, and trade credit are 17.6 percent, 12.7 percent, 32.5 percent, and 37.2 percent, respectively. Corresponding likelihoods for a fifty year old owner, median aged, are 20.6 percent, 10.9 percent, 30.5 percent, and 38.0 percent. Figures for 60 year old are 24.1 percent, 9.2 percent, 28.3 percent, and 38.4 percent. As for the conditional choice of source of credit, the effect on the conditional likelihood of choosing trade credit is positive and statistically significant. Effects of the other two alternatives are negative but not statistically significant.

The firm's demography and its financial choice

Firms whose owner has advanced degrees (degree granting college or higher) are more likely to choose trade credit and less likely to choose lending only than firms owned by the less educated. Minority owners are more likely to choose institutional lending and less likely to be either exclusively dependent on trade credit or to be self-financed (no demand for external credit). Female owners are less likely to seek external credit. They are likely to choose lending only over other financing alternatives if they consider applying for some external credit. Family owned firms are less likely

\footnotetext{
${ }^{33}$ This may indicate that the terms of borrowing contracts in general are unfavorable to older individuals. Interest rates charged may also be higher. Faced with only expensive credits are available, they would choose to be self-financed.
} 
to seek external credit than non-family owned firms.

None of the region dummies except a few entries are statistically significant. The estimated marginal effects of these dummy variables are not small, but accompanying standard errors are large. ${ }^{34}$ None of industry dummies are statistically significant. ${ }^{35}$

\subsection{Discussion}

The firm's information availability and its financial choice

Records of the firm's accounting and management may not be publicly available but lenders may have access to them upon their request to the borrowing firm. Firms whose information is poorly recorded are more likely to choose institutional (bank) lending than those with better records and less likely to choose trade credit. In contrast firms that record hard information are unlikely to be bank dependent, and more likely to attempt to borrow from both banks and supplier firms.

Such findings are consistent with the view that specialist lenders can obtain information about borrowers from undocumented sources. Such lenders are equipped with the expertise for handling information, and are able to obtain the information of borrowing firms not only through written documents or electronic documents recorded and kept by firms but also through less formal measures such as meetings, phone conversations, and on site inspections of the borrowers' production facilities, operating sales sites, and so on. Specialist lenders, then, process such soft information to assess the viability

\footnotetext{
${ }^{34}$ The estimated marginal effects on the unconditional likelihood as well as on the likelihood conditional on the firm's demand of credit imply that firms in East North Central are more likely to choose lending only than firms elsewhere. The estimated marginal effect on the unconditional likelihood for firms in West South Central is negative and statistically significant . These effects, however, are only statistically significant at the 10 percent significance level.

${ }^{35}$ There are several large point estimates of marginal effects that draw our attention. The results on both unconditional and conditional probabilities suggest that firms in construction and manufacturing industries are more likely to use trade credit (a large positive sum of entries for trade credit and the mix of lending and trade credit), and that those in communication and transportation, and finance industries are less likely to use trade credit (a large negative sum of entries for trade credit and the mix of lending and trade credit). Results on conditional probabilities of choosing a financial alternative suggest that firms in construction and manufacturing are less likely to choose lending only, and that those in communication and transportation, and finance industries are more likely to choose lending only.
} 
of borrowers. In other words, specialist lenders are able to read between the lines of written documents with their special monitoring technology and can offer the cheap credits to informationally opaque firms.

Unlike specialist lenders, non-specialist lenders, represented by good supplying firms that allow buyers late payments, are less likely to possess such expertise. However, through daily transactions and delivery of goods and services they may have as close relationships with borrowing firms as specialist lenders. They can exert leverage on a borrowing buyer by threatening to cut off the future supply of goods and services if they ever detect a bad signal from a borrower. Such bargaining power could be the reason that supplier firms can act as non-specialist intermediaries. ${ }^{36}$ Yet, our findings imply that such supplier firms perhaps lack the ability to collect and process soft information from borrowers, which is not as readily available as recorded documents or electronic files. Therefore they do not offer cheap trade credit to informationally opaque firms. As a consequence the optimal choice for firms with poor management and accounting records is to seek cheaper institutional borrowing and try not to rely on trade credit.

There are possibly two reasons why firms do not switch entirely to trade credit but to seek to add trade credit as an adjunct to institutional borrowing. First, institutional borrowing could involve the substantial fixed transaction costs for a borrower firm. Giving up bank loans entirely would waste the firm's investment of such costs. Second, many firms' motives for using trade credit are not restricted to the financial. For instance they may use trade credit to smooth transactions by reducing the number of bills paid. ${ }^{37}$ In this case firms choosing trade credit only could constitute a group of such firms with non-financial motives.

Less publicly recognized firms, young firms with few branches, are also less likely to choose bank lending over trade credit, supporting our findings concerning the availability of the firm's private information to lenders. These findings are consistent with the findings of Petersen and Rajan $(1994,1995)$ that costs of institutional lenders fall as a firm's age. Our findings show that the direct and indirect costs of trade credit, which is provided by a nonspecialist, is more sensitive to a firm's age than is the institutional lending.

Interpreting measures of transparency, particularly the variables such as owner experience and a firm's age needs caution. First, it is the availability

\footnotetext{
${ }^{36}$ See Petersen and Rajan (1997) on the supplier firm's bargaining advantage.

${ }^{37}$ Petersen and Rajan (1997) provide non-financial motives of use of trade credit.
} 
and quality (accuracy) of information to the lenders per se that matters in determining the terms of the lending contract and whether or not the firm allows lenders private access to its information or the information is made publicly available is less important. Even though a long period of doing business and multiple business locations may make the firm well recognized in the local community, it may not provide the accounting and management information that lenders need. Furthermore, the owner's business experience and the firm's age may involve the classical sample selection bias, and capture not only the firm's public recognition but also the talents and performance of the firm and its owner. A long business history could mean that the firm has outperformed its market competitors year after year. Alternatively, it could imply that the firm has lagged behind other firms that have grown much faster and become large entities. Younger firms are likely to demand longer-term credits for financing setup costs regardless of their transparency. Public recognition seems to encourage a firm to switch from bank dependence to exclusive trade credit financing rather than mixing its demand for both.

Inventory management and trade credit

Large but statistically insignificant industry effects on use of trade credit are observed in the positive effects of construction and manufacturing industries and the negative effects of communication and transportation, and the finance industries. No effect is seen in wholesale, retail, and services industries. Petersen and Rajan (1997) tell us that trade credit serves as a device for supplier firm to manage its inventories efficiently. A supplier may offer trade credit on sales of goods beyond its warehousing capacity to customers that have a better ability to carry them. Manufacturing firms usually have large warehouses for intermediate and final goods. Likewise construction companies have a large quantity of equipment, machinery, and building materials to store. Thus these industries are more likely to buy intermediate and final goods through trade credit arrangements. That there is no recognizable effect on the services industry is not inconsistent with its limited ability for storing materials. Though they are not definitive, the observed industry effects are largely consistent with the economic prediction.

Some caveats

There is the potential that independent variables are not exogenous and cause a simultaneity bias. For instance, the feedback effect from a firm's choice of a borrowing pattern to the variable PCFMAN may result. Suppose there are two lenders, an institutional lender and a goods (services) supplier firm to the borrowing firm. If one of them required the borrowing firm 
to submit its accounting records or the business plans, the borrowing firm, which previously had not used computers for accounting would now have an incentive to utilize its computer resources or buy new ones for keeping up and organizing its accounting. Then the marginal effect of PCFMAN on the likelihood of choosing the lender requesting such documents conditional on the firm's need for external credit would be biased upwardly. Similarly if the borrowing firm needed the well organized bookkeeping for repaying to specifically one of two, the marginal effect on the conditional likelihood of choosing the lender would be biased upwardly again.

However, such a bias would be likely only to underestimate our findings. Trade credit is the medium of short term credit and the lender firm is less likely to require the submission of specific documents on the firm's accounting or management. ${ }^{38}$ On the other hand, an institutional lender as a provider of longer term credit would request such documents from a borrower more frequently than a trade credit providing firm. As for the firm's voluntary use of computers for planned repayments, the longer term loans would require more detailed planning and involve more complicated calculations than trade credit. This implies that correcting biases, if there were any, would reinforce our conclusions even more.

Timings of institutional borrowing vary across the three year period prior to the date of polling of the firms, whereas timings of trade credit contracts span the one year period prior to the date of inquiries. ${ }^{39}$ On the other hand, the survey questions the firm's current informational characteristics at the date of inquiries. Thus, unfortunately, independent variables are not predetermined. It would be idealistic if the data on the availability of the firm's information before the three-year period prior to the date of inquires for each firm were available to us so that independent variables could be predetermined.

This, however, does not cause a serious problem of simultaneity bias for the following two reasons. The constructed dependent variable collects applications to the same type of credit source into a single group, and captures the static (structural) preference of the firm. The construction of the variable does not take into account the frequency of applications for each type

\footnotetext{
${ }^{38}$ The firm would simply use the generic rating services such as Dun \& Bradstreet credit scoring if necessary.

${ }^{39}$ A date of survey for each firm varies in the two year period from 1999 to 2000. Therefore, a timing of an attempted institutional borrowing covered ranges from 1996 to 2000. Likewise a timing of an attempted trade credit contract ranges from 1998 to 2000.
} 
of credit source. Therefore, in the empirical exercise, we are examining the structural relationship between static properties of the firm, implying that the timing of events is of little relevance. Our economic interpretation of the results has relied on the findings with regard to PCFMAN, which is one of the few independent variables that could capture the timing of an event as well as static characteristics. As for this variable, it is the timing of the firm's introduction of computers for accounting purposes that is relevant to the claim. If the firm had introduced them later than the firm's most recent application from each source, the variable would be indeed predetermined. However, even if it is a late user of computers for bookkeeping, such a firm is likely to have kept better accounting records with low technology methods including hard copies of well organized and detailed books and timely accounting statements. The firm that uses computers just for online shopping, emailing, and web surfing at the time of the survey (1999-2000) is less likely to have kept better records than the firm with some level of computerized accounting system. In other words, PCFMAN is not only the direct measure of the availability of the firm's records but also the indirect measure of the more general stance of the firm on recording information.

\section{Conclusion}

The main purpose of this paper is to present the empirical findings from the 1998 Survey of Small Business Finances that the availability of private and public information on the borrower firm and other informational characteristics of the firm leads to diverse borrowing patterns among borrower firms.

Small firms often portrayed as being exclusively bank dependent in fact also use trade credit as a source of external credit. The share of external credit in small business finance is as dominant as institutional loans. Though term structures of the two forms of finance differ, use of trade credit leaves the average balance in the firm's balance sheet just as using an institutional lender would. As a total financial management, the firm makes a choice between institutional borrowing and trade credit.

Institutional lenders are specialized in financial services whereas trade credit providing firms play a dual role of non-financial service provider and lending service provider. Therefore, theoretically, institutional lenders, who are specialist lenders, emerge only when they are substantially more efficient 
in monitoring and assessing the viability of borrower firms than non-financial firms granting trade credit. Whether the firm that allows that accounting and management information be made available to lenders chooses institutional borrowing or trade credit is an empirical question.

We explored a family of probabilistic logit models to characterize the firms' choice of a financial source. Constructing the four state dependent variable that indicates whether firms applied to external credit or not, and if it did whether the source is trade credit, institutional lending, or both of them, we then estimated how the availability of private and public information about the firm to lenders affects the likelihood, particularly the likelihood conditional on the firm's need for credit, that the firm would choose each credit source. We paid special attention to the variable PCFMAN, the dummy variable indicating whether the firm employs computers for accounting or not, which is based on the new questionnaires that appears for the first time in the 1998 version of the SSBF. The variable overcomes the shortcomings of other preexisting variables.

We find that firms whose information is poorly recorded, or that are publicly less recognized, are more likely to choose institutional lending over trade credit. As recorded information is better organized and firms become more transparent, they tend to switch to a greater use of trade credit. This finding is robust across various measures of availability of information to lenders. Our empirical findings are consistent with the classical hypothesis which claims that institutional lenders are capable of auditing borrowers regardless of the availability of the recorded information. Firms with better private recorded information tend to keep using bank lending as well as further use of trade credit rather than switching entirely to trade credit. This may indicate that the application for bank lending involves substantial transaction costs and that firms would prefer not to waste such fixed costs.

\section{References}

Amemiya, Takeshi (1985), "Advanced Econometrics", Harvard University Press.

Berger, Allen N. and Gregory F. Udell (1995), "Relationship Lending and Lines of Credit in Small Firm Finance", Journal of Business, 68 (3): $351-81$. 
Berger, Allen N., Leon F. Klapper and Gregory F. Udell (2001), "The Ability of Banks to Lend to Informationally Opaque Small Businesses", Journal of Banking and Finance, 25 (12): 2127-67.

Bernanke, Ben S., Mark Gertler and Simon Gilchrist (1999), "The Financial Accelerator in a Quantitative Business Cycle Framework", Handbook of macroeconomics. Volume 1C: 1341-93.

Bolton, Patrick and Xavier Freixas (2000 a), "Equity, Bonds, and Bank Debt: Capital Structure and Financial Market Equilibrium Under Asymmetric Information", Journal of Political Economy, 108 (2): 324-51.

Bolton, Patrick and Xavier Freixas (2000 b), "Corporate Finance and the Monetary Transmission Mechanism", mimeo, Princeton University and Universitat Pompeu Fabra.

Bond, Phillip (2004), "Bank and Non-bank Financial Intermediation", forthcoming in the Journal of Finance.

Cole, Rebel A. (1998), "The Importance of Relationships to the Availability of Credit", Journal of Banking and Finance, 22 (6-8): 959-77.

Diamond, Douglas W. and Raghuram G. Rajan (2000), "A Theory of Bank Capital", Journal of Finance 55 (6): 2431-65.

Diamond, Douglas W. and Raghuram G. Rajan (2001), "Liquidity Risk, Liquidity Creation, and Financial Fragility: A Theory of Banking", Journal of Political Economy, 109 (2): 287-327.

Degryse, Hans and Patrick Van Cayseele (2000), "Relationship Lending within a Bank-Based System: Evidence from European Small Business Data", Journal of Financial Intermediation, 23 (9): 90-109.

Duffie, Darrell and David Lando (2001), "Term Structures of Credit Spreads with Incomplete Accounting Information", Econometrica, 69 (3): 63364.

Freixas, Xavier and Jean-Charles Rochet (1997), "Microeconomics of Banking", The MIT Press. 
Holmstrom, Bengt and Jean Tirole (1997), "Financial Intermediation, Loanable Funds, and the Real Sector", Quarterly Journal of Economics, 112 (3) 663-91.

Hoshi, Takeo, Anil K. Kashyap and David Scharfstein (1991), "Corporate Structure, Liquidity, and Investment: Evidence from Japanese Industrial Group", Quarterly Journal of Economics, 106 (1) 33-60.

Kashyap, Anil K, Raghuram G. Rajan and Jeremy C. Stein (2002), "Banks as Liquidity Providers: An Explanation for the Coexistence of Lending and Deposit-Taking", Journal of Finance 57 (1): 33-73.

Ng, Chee K., Janet Kiholm Smith, and Richard L. Smith (1999), "Evidence on the Determinants of Credit Terms Used in Interfirm Trade", Journal of Finance 54 (3): 1109-29.

Petersen, Mitchell A. and Raghuram G. Rajan (1994), "The Benefits of Lending Relationships: Evidence from Small Business Data", Journal of Finance 49 (1): 3-37.

Petersen, Mitchell A. and Raghuram G. Rajan (1997), "Trade Credit: Theories and Evidence", Review of Financial Studies 10 (3): 661-91.

Petersen, Mitchell A. and Raghuram G. Rajan (2002), "Does Distance Still Matter? The Information Revolution in Small Business Lending", Journal of Finance 57 (6): 2533-70.

Townsend, Robert E. (1979), "Optimal Contracts and Competitive Markets with Costly State Verification", Journal of Economic Theory 21: 26593.

Williamson, S. (1987), "Costly Monitoring, Loan Contracts, and Equilibrium Credit Rationing", Quarterly Journal of Economics 102 (1): 13545.

Yu, Fan (2002), , "Accounting Transparency and the Term Structure of Credit Spreads", mimeo, Graduate School of Management, University of California, Irvine. 


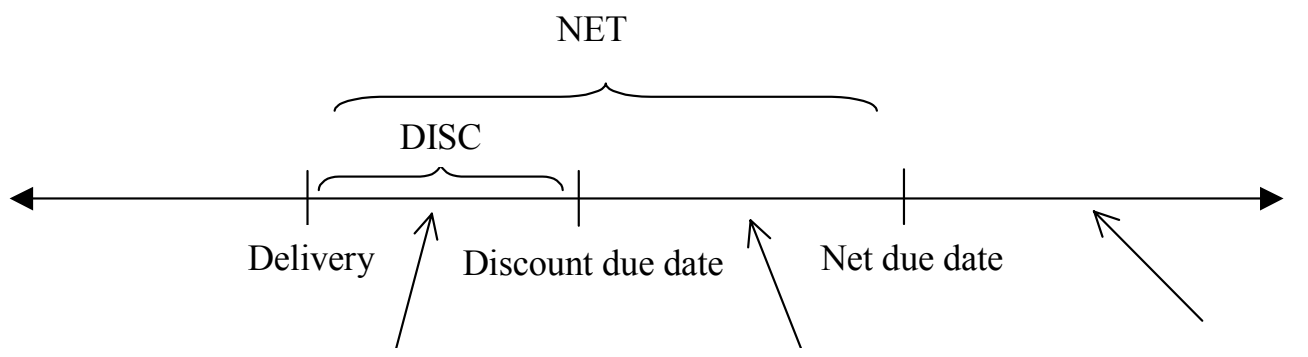

Discount rate to the purchased goods : No discount, no penalty Penalty rate applies

Figure 1: Contractual details of trade credit

Intermediation by an entrepreneur 1 (non-specialist)

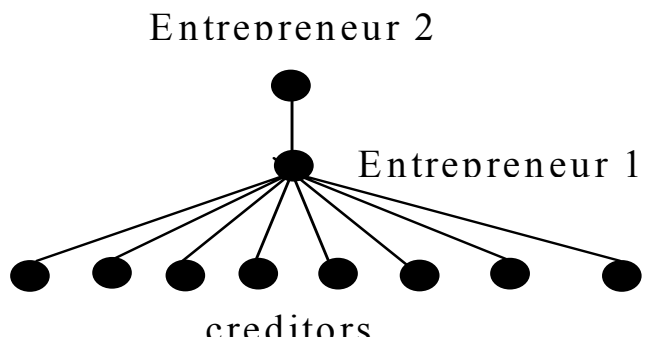

Intermediation by one of creditors (specialist)

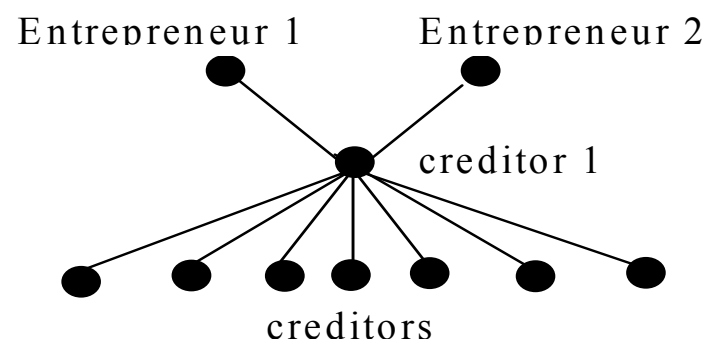

Figure 2: Specialist and non-specialist lenders (from Bond (2004)) 
Multinomial logit

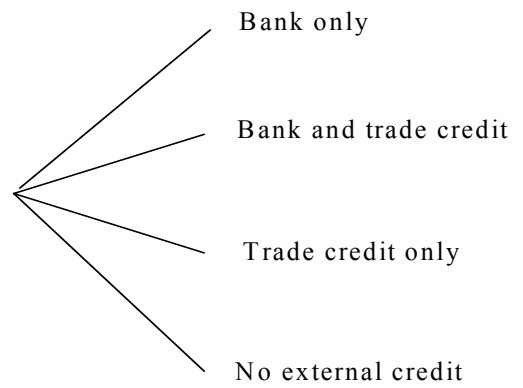

Nested logit

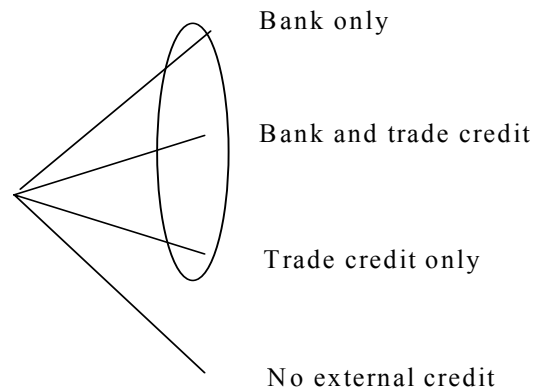

Nested multinomial logit

Stage 2

Bank only
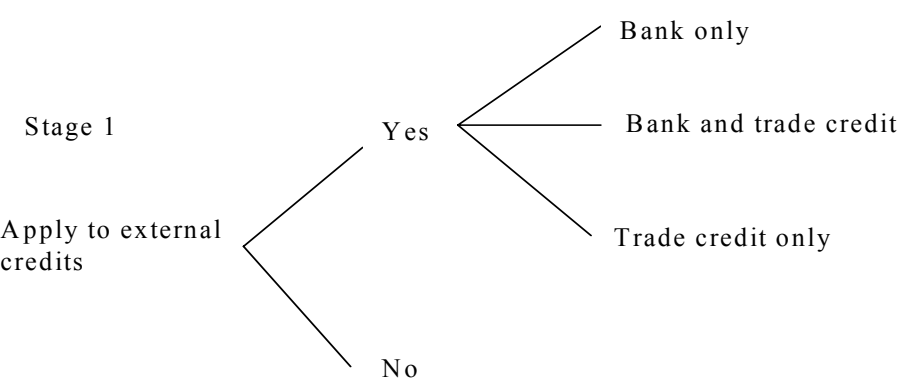

Figure 3: Decision trees of logit models 
Unconditional probabilities

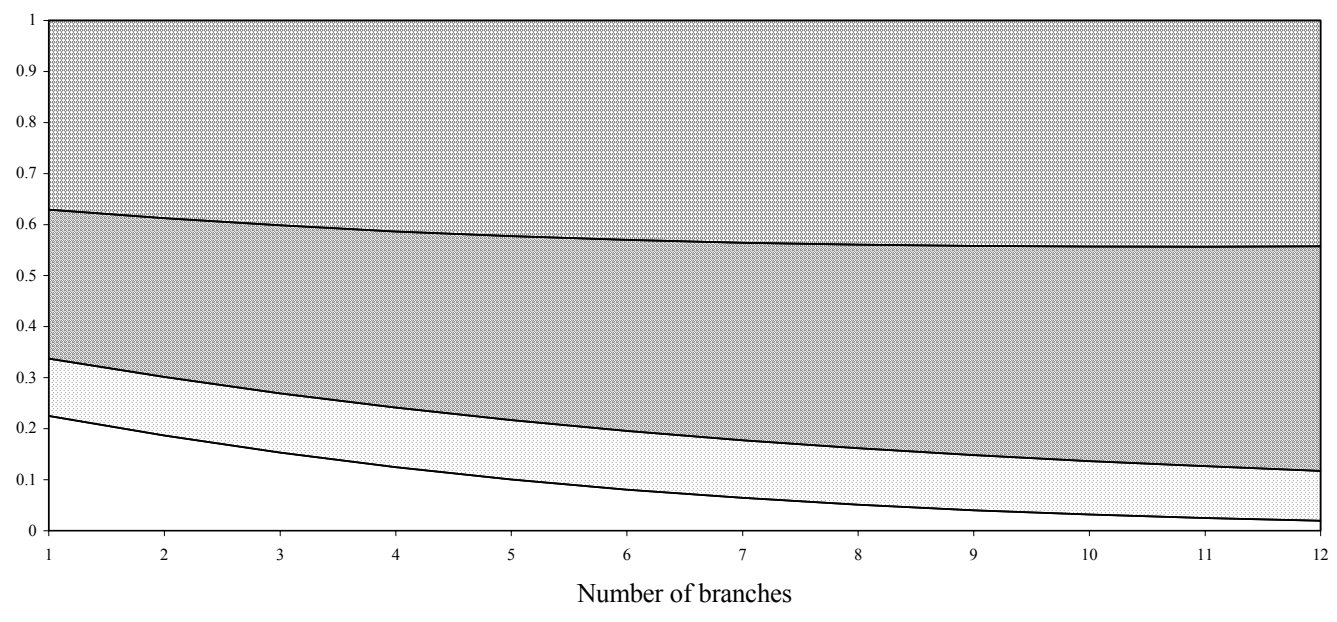

$\square$ No external credit $\square$ Lending only $\square$ Lending/Trade credit $\square$ Trade credit only

Conditional probabilities

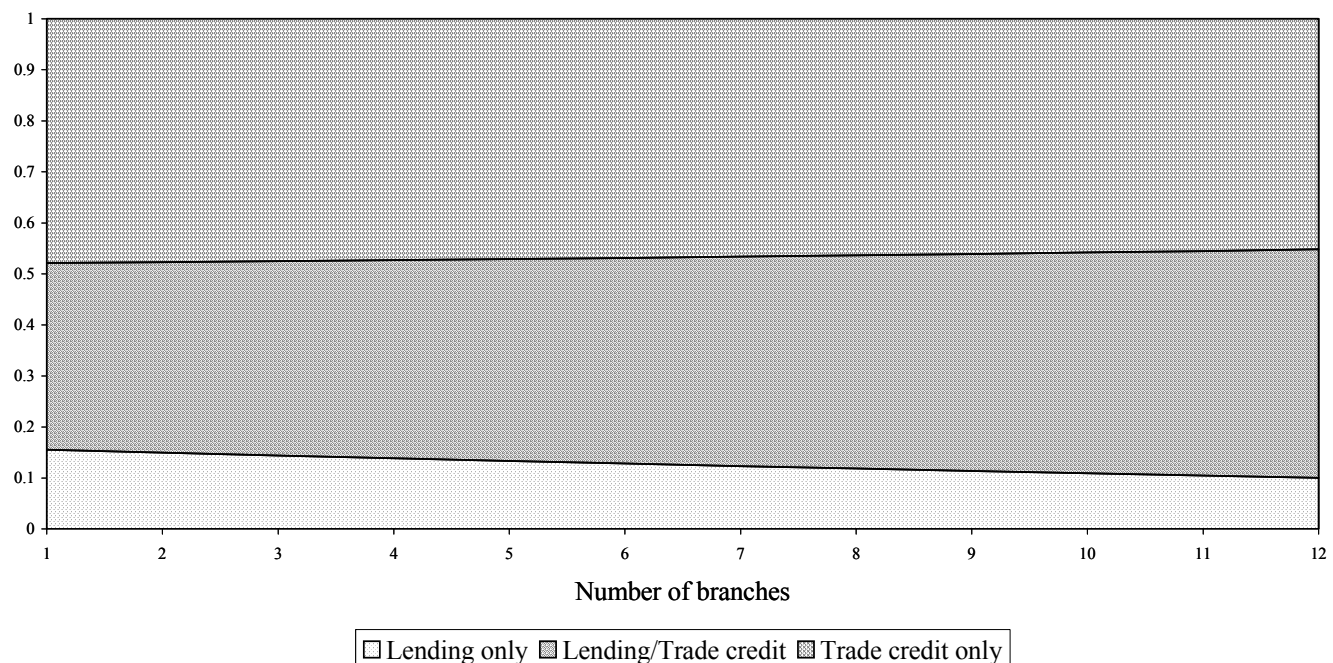

$\square$ Lending only $\square$ Lending/Trade credit $\square$ Trade credit only

Figure 4: Number of branches and financial choice 
Unconditional Probabiities

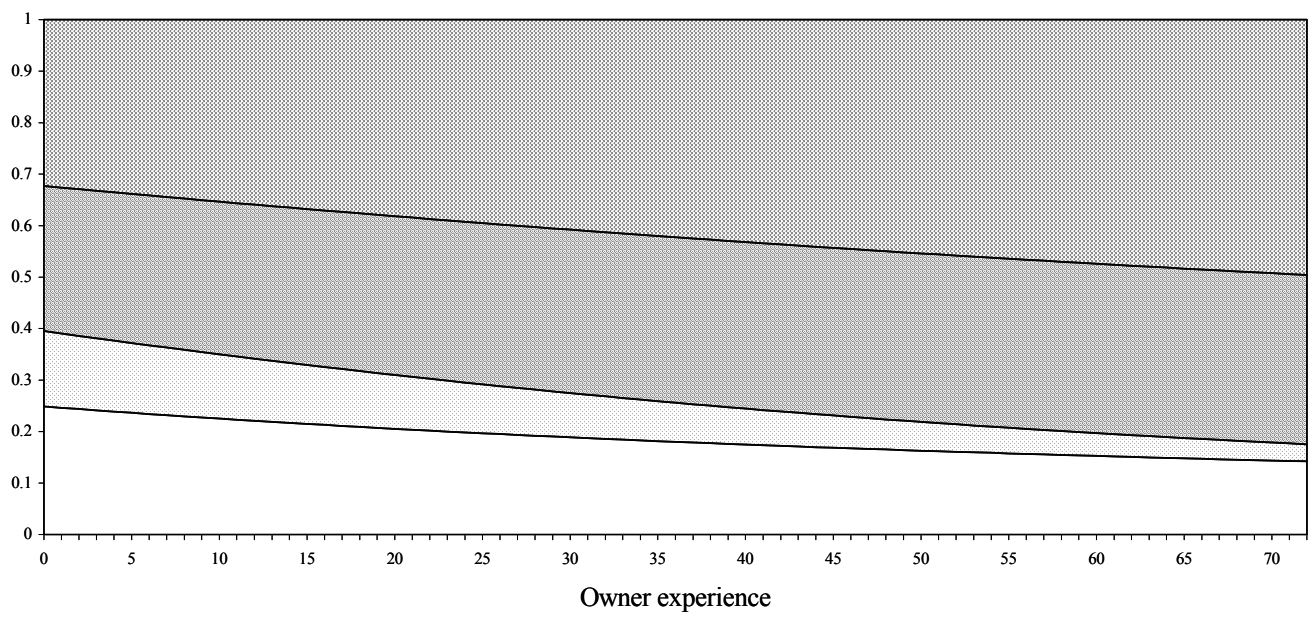

$\square$ No external credit $\square$ Lending only $\square$ Lending/Trade credit $\square$ Trade credit only

Conditional Probabilities

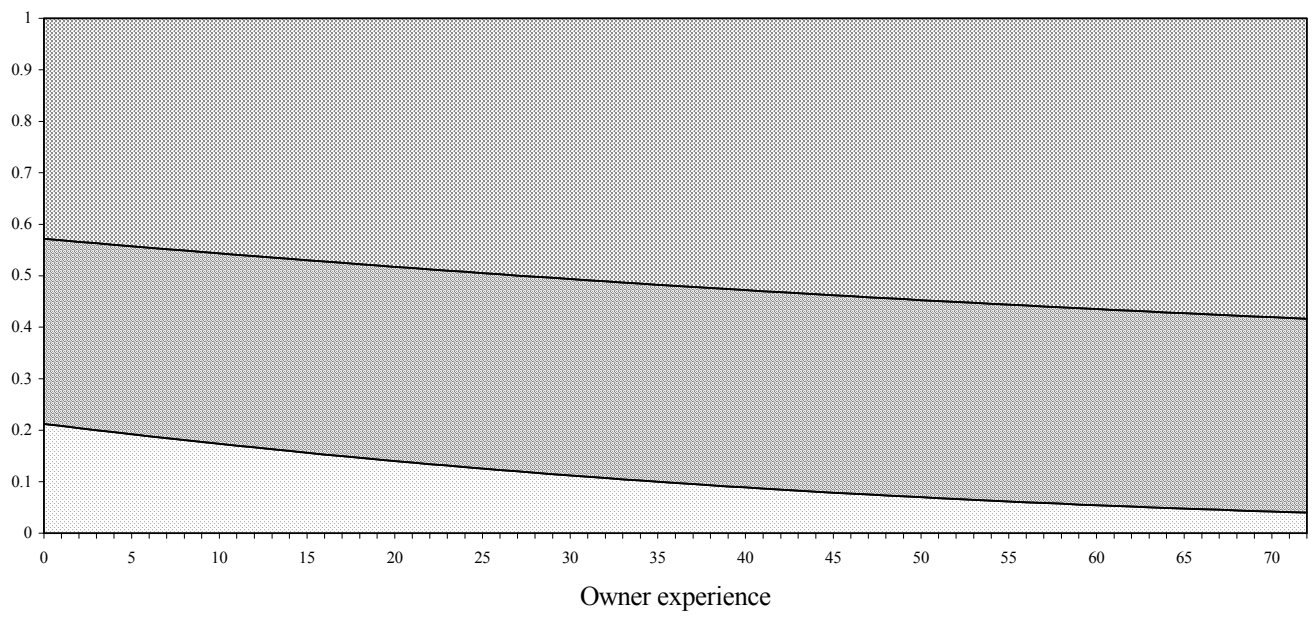

$\square$ Lending only $\square$ Lending/Trade credit $\square$ Trade credit only

Figure 5: Owner experience and financial choice 
Unconditional probabilities



$\square$ No external credit $\square$ Lending only $\square$ Lending/Trade credit $\square$ Trade credit only

Conditional probabilities

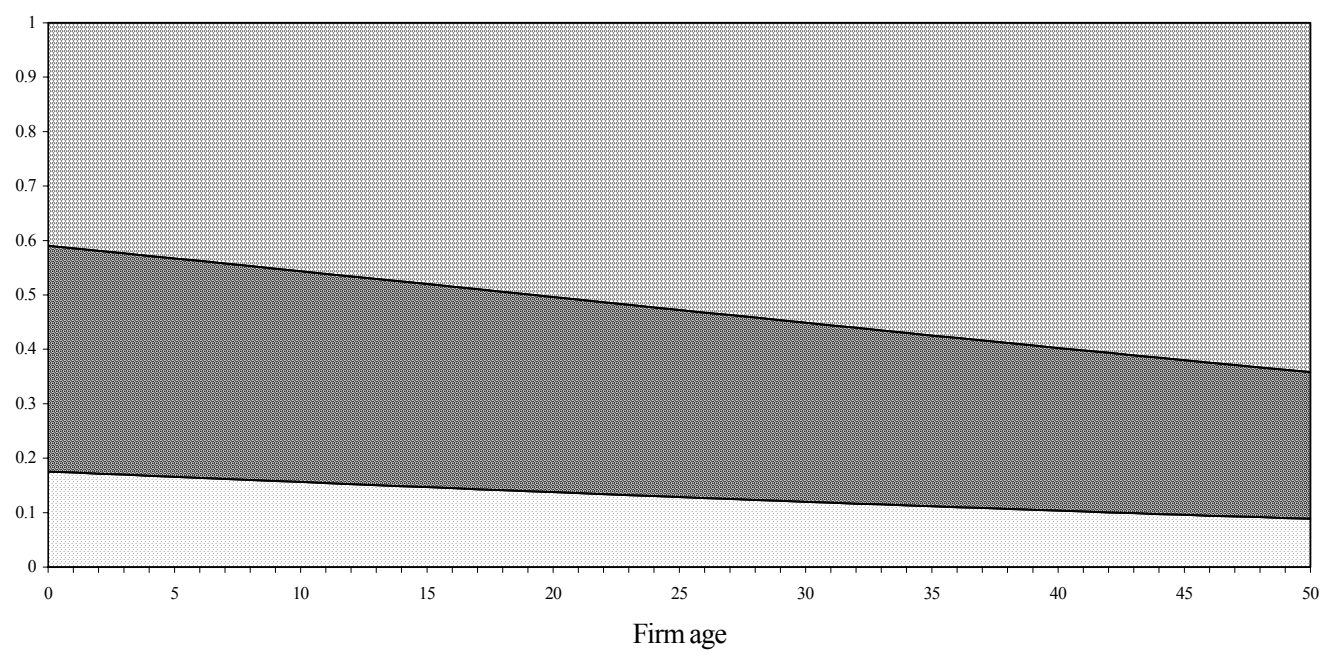

$\square$ Lending only $\square$ Lending/Trade credit $\square$ Trade credit only

Figure 6: Firm age and financial choice 
Unconditional Probabilities

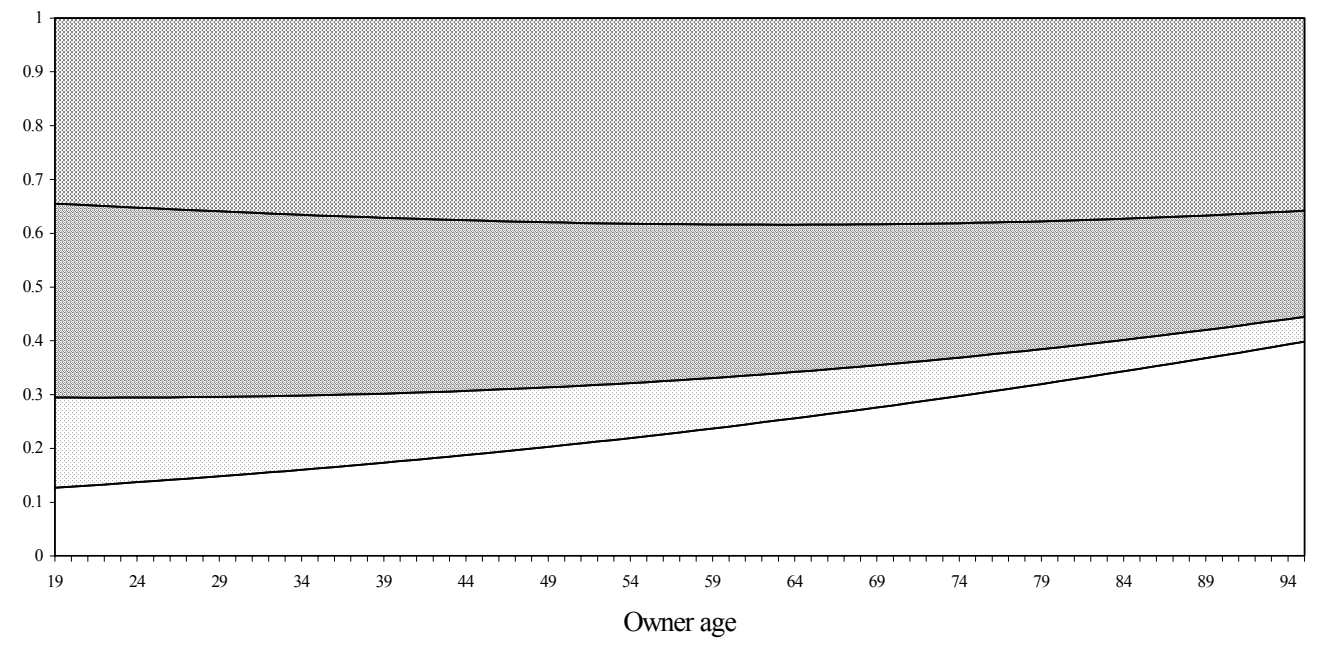

$\square$ No external credit $\square$ Lending only $\square$ Lending/Trade credit $\square$ Trade credit only

Conditional Probabilities

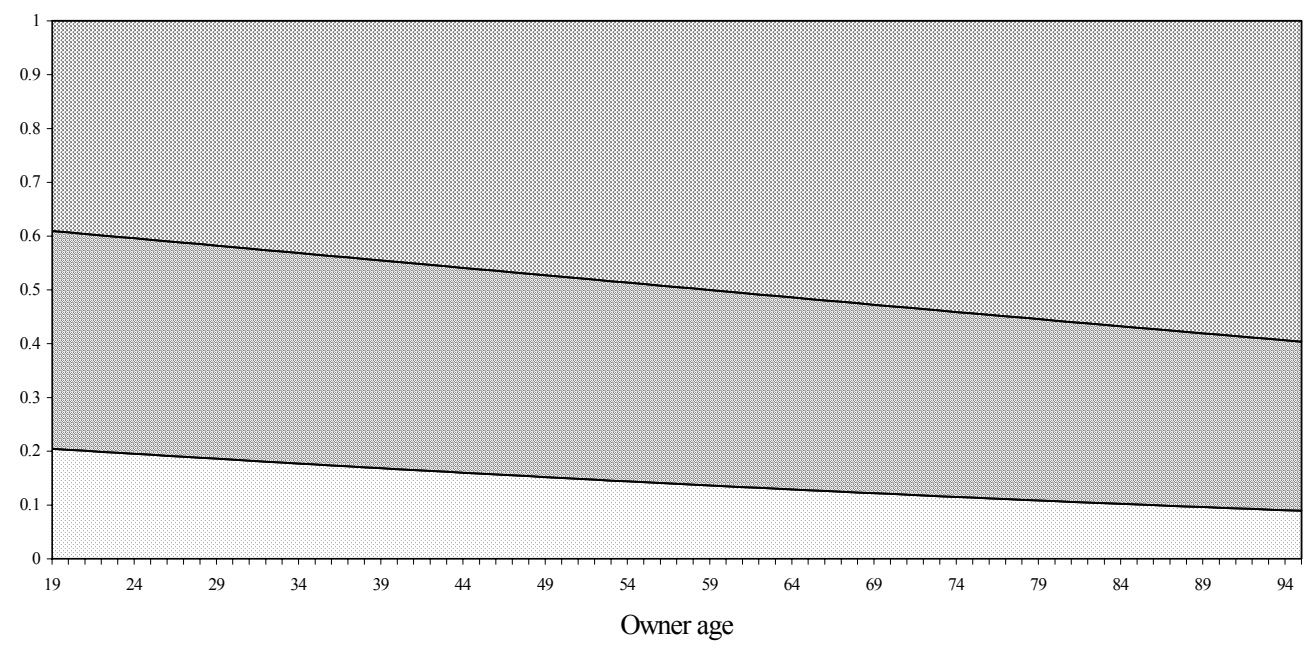

$\square$ Lending only $\square$ Lending/Trade credit $\square$ Trade credit only

Figure 7: Owner age and financial choice 
Table 1 Descriptive statistics on the variables used to construct the dependent variable

\begin{tabular}{|c|c|c|}
\hline & Voluntary & hdrawal \\
\hline & Yes & No \\
\hline zero & 487 & 2046 \\
\hline $\mathrm{ZCH}$ & 63.0 & 75.5 \\
\hline Frequency & 114 & 318 \\
\hline new loans & 14.8 & 12.8 \\
\hline more than & 172 & 347 \\
\hline once & 22.3 & 11.7 \\
\hline total & 773 & 2711 \\
\hline & 22.2 & 77.8 \\
\hline
\end{tabular}

Top entries are frequencies. Bottom entries for individual items are proportions to the column total, and those for "Total" are proportions to the entire sample size.

\begin{tabular}{|c|c|c|c|}
\hline & \multicolumn{2}{|c|}{ Applications } \\
\hline & & approved & denied \\
\hline \multirow{10}{*}{ Institutions } & \multirow{2}{*}{$\begin{array}{l}\text { commercial } \\
\text { bank }\end{array}$} & 395 & 108 \\
\hline & & 50.1 & 44.8 \\
\hline & \multirow{2}{*}{$\begin{array}{l}\text { savings } \\
\text { bank }\end{array}$} & 159 & 49 \\
\hline & & 20.2 & 20.3 \\
\hline & \multirow{2}{*}{ S\&L } & 126 & 32 \\
\hline & & 16.0 & 13.3 \\
\hline & \multirow{2}{*}{ credit union } & 44 & 25 \\
\hline & & 5.6 & 10.4 \\
\hline & \multirow{2}{*}{ non-bank } & 65 & 27 \\
\hline & & 8.2 & 11.2 \\
\hline & total & 789 & 241 \\
\hline
\end{tabular}

Top entries are frequencies. Bottom entries are proportions to the column total.

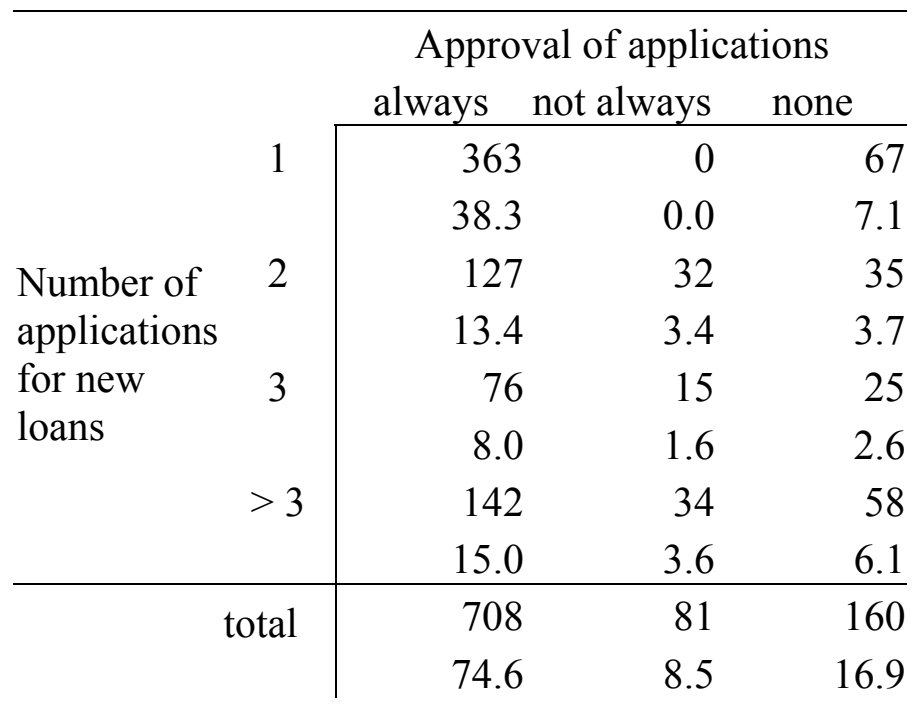

Top entries are frequencies. Bottom entries are proportions to the entire sample size.

\begin{tabular}{|c|c|c|c|}
\hline & \multicolumn{2}{|c|}{ Trade credit denied } \\
\hline & & yes & no \\
\hline \multirow{4}{*}{$\begin{array}{l}\text { Use of trade } \\
\text { credit }\end{array}$} & yes & 172 & 2147 \\
\hline & & 5.0 & 61.8 \\
\hline & no & 34 & 1124 \\
\hline & & 1.0 & 32.3 \\
\hline & total & 206 & 3271 \\
\hline & & 5.9 & 94.1 \\
\hline
\end{tabular}

Top entries are frequencies. Bottom entries are proportions to the entire sample size. 
Table 4 Panel A Parameter estimates (Nested logit and multinomial logit models)

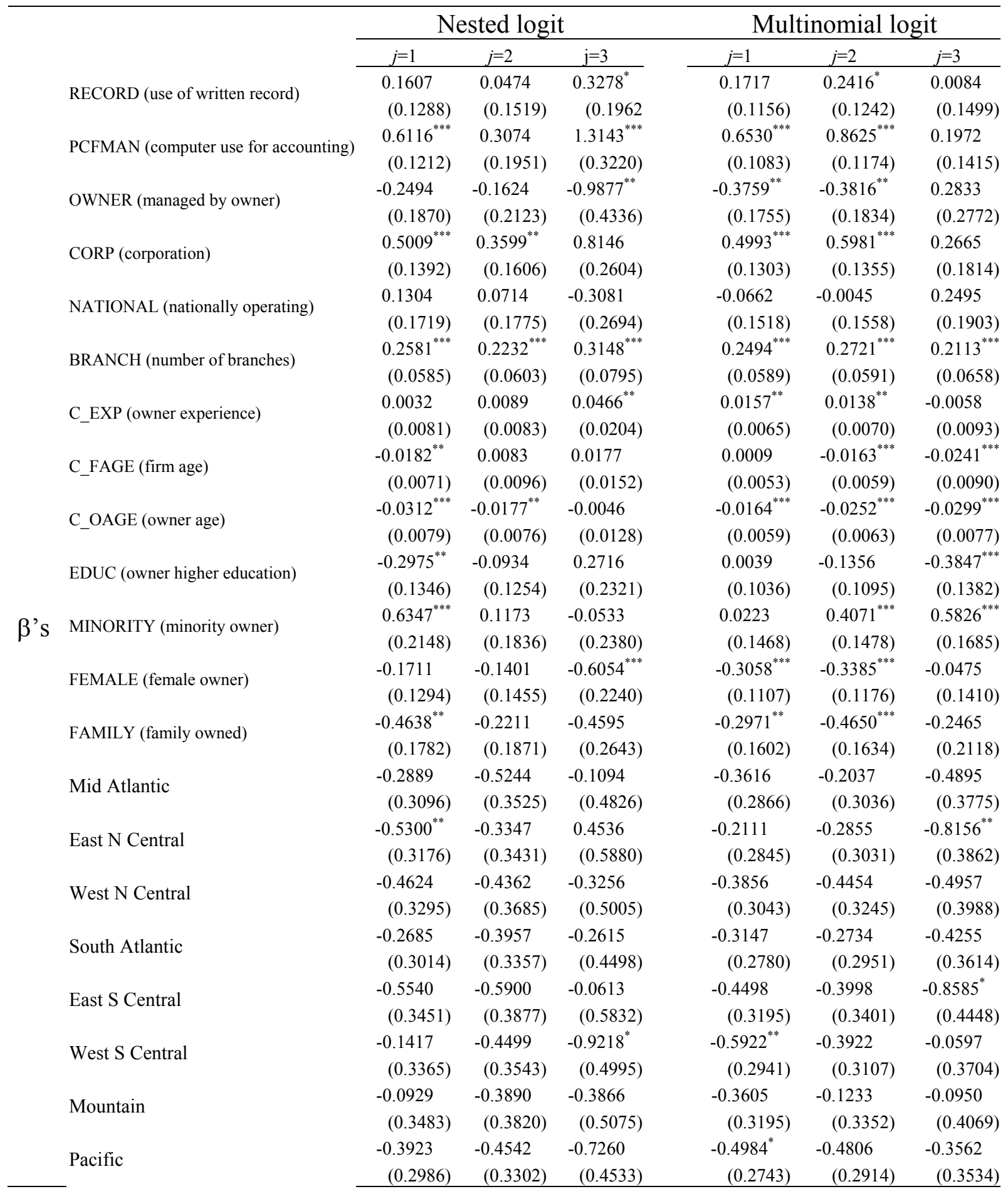




\begin{tabular}{|c|c|c|c|c|c|c|c|}
\hline & & \multicolumn{3}{|c|}{ Nested logit } & \multicolumn{3}{|c|}{ Multinomial logit } \\
\hline \multirow{9}{*}{$\beta^{\prime} \mathrm{s}$} & & $j=1$ & $j=2$ & $j=3$ & $j=1$ & $j=2$ & $j=3$ \\
\hline & Construction & $\begin{array}{l}0.3459 \\
(0.9707)\end{array}$ & $\begin{array}{l}0.2196 \\
(1.0206)\end{array}$ & $\begin{array}{l}1.7424 \\
(1.4127)\end{array}$ & $\begin{array}{l}0.7256 \\
\quad(0.9113)\end{array}$ & $\begin{array}{l}0.5686 \\
(0.9086)\end{array}$ & $\begin{array}{r}-0.6068 \\
(1.0737)\end{array}$ \\
\hline & Manufacturing & $\begin{array}{l}0.4200 \\
(0.9706)\end{array}$ & $\begin{array}{l}0.3075 \\
(1.0168)\end{array}$ & $\begin{array}{l}1.5851 \\
(1.3928)\end{array}$ & $\begin{array}{l}0.7146 \\
\quad(0.9119)\end{array}$ & $\begin{array}{l}0.5711 \\
(0.9090)\end{array}$ & $\begin{array}{r}-0.4039 \\
(1.0729)\end{array}$ \\
\hline & Communication/transportation & $\begin{array}{r}-0.1758 \\
(1.0181)\end{array}$ & $\begin{array}{r}-0.7457 \\
(1.0283)\end{array}$ & $\begin{array}{r}-1.3744 \\
(1.3548)\end{array}$ & $\begin{array}{l}-0.9555 \\
\quad(0.9297)\end{array}$ & $\begin{array}{r}-0.7189 \\
(0.9206)\end{array}$ & $\begin{array}{r}-0.2369 \\
(1.0713)\end{array}$ \\
\hline & Wholesale & $\begin{array}{r}-0.1718 \\
(0.9743)\end{array}$ & $\begin{array}{l}0.1332 \\
(1.0169)\end{array}$ & $\begin{array}{l}0.2567 \\
(1.3322)\end{array}$ & $\begin{array}{l}0.2670 \\
\quad(0.9141)\end{array}$ & $\begin{array}{r}-0.1456 \\
(0.9129)\end{array}$ & $\begin{array}{r}-0.4184 \\
(1.0719)\end{array}$ \\
\hline & Retail & $\begin{array}{r}-0.2662 \\
(0.9613)\end{array}$ & $\begin{array}{l}0.1067 \\
(1.0006)\end{array}$ & $\begin{array}{l}0.5083 \\
(1.3099)\end{array}$ & $\begin{array}{l}0.3386 \\
\quad(0.9005)\end{array}$ & $\begin{array}{l}-0.1440 \\
(0.8983)\end{array}$ & $\begin{array}{r}-0.6010 \\
(1.0504)\end{array}$ \\
\hline & Finance & $\begin{array}{r}-1.0095 \\
\quad(0.9767)\end{array}$ & $\begin{array}{l}-0.3165 \\
(1.0699)\end{array}$ & $\begin{array}{l}-2.3693 \\
(1.4404)\end{array}$ & $\begin{array}{l}-0.9573 \\
\quad(0.9110)\end{array}$ & $\begin{array}{r}-1.6460^{*} \\
(0.9153)\end{array}$ & $\begin{array}{r}-0.5211 \\
(1.0586)\end{array}$ \\
\hline & Services & $\begin{array}{r}-0.6417 \\
(0.9556)\end{array}$ & $\begin{array}{l}-0.2980 \\
(0.9967)\end{array}$ & $\begin{array}{l}-0.5832 \\
(1.2971)\end{array}$ & $\begin{array}{r}-0.2569 \\
(0.8964)\end{array}$ & $\begin{array}{r}-0.7256 \\
(0.8936)\end{array}$ & $\begin{array}{r}-0.6258 \\
(1.0427)\end{array}$ \\
\hline & Constant & $\begin{array}{l}4.1662 \\
(83.5458)\end{array}$ & $\begin{array}{c}3.2854 \\
(83.5403)\end{array}$ & $\begin{array}{c}3.0760 \\
(83.5437)\end{array}$ & $\begin{array}{l}1.1752 \\
(1.0065)\end{array}$ & $\begin{array}{l}1.8882^{*} \\
(1.0144)\end{array}$ & $\begin{array}{l}1.7691 \\
(1.2050)\end{array}$ \\
\hline$a$ & & $\begin{array}{c}1.7236 \\
(143.9665) \\
-1.4681^{* *} \\
(0.6273)\end{array}$ & & & & & \\
\hline \multicolumn{2}{|c|}{ Maximized likelihood } & \multicolumn{3}{|c|}{-4177.3456} & \multicolumn{3}{|c|}{-4185.2554} \\
\hline
\end{tabular}

***,**, and * show that a coefficient is statistically significant at the 1 percent, the 5 percent, and the 10 percent level, respectively. Symbols mean the same in coming tables. 
Table 4 Panel B Parameter estimates (Nested multinomial logit model)

\begin{tabular}{|c|c|c|c|c|}
\hline & & First stage logit & Second stage mu & omial logit \\
\hline & & $j \neq 1$ & $j=2$ & $j=3$ \\
\hline & RECORD (use of written record) & $\begin{array}{l}0.1602 \\
(0.1034)\end{array}$ & $\begin{array}{l}0.0725 \\
(0.1083)\end{array}$ & $\begin{array}{r}-0.1501 \\
(0.1466)\end{array}$ \\
\hline & PCFMAN (computer use for accounting) & $\begin{array}{c}0.6386^{* * *} \\
(0.0962)\end{array}$ & $\begin{array}{l}0.2050^{*} \\
(0.1057)\end{array}$ & $\begin{array}{r}-0.4903^{* * *} \\
(0.1392)\end{array}$ \\
\hline & OWNER (managed by owner) & $\begin{array}{r}-0.3012 \\
(0.1644)\end{array}$ & $\begin{array}{c}-0.0258 \\
(0.1315)\end{array}$ & $\begin{array}{r}0.6085^{* *} \\
(0.2567)\end{array}$ \\
\hline & CORP (corporation) & $\begin{array}{l}0.4994^{* * *} \\
(0.1215)\end{array}$ & $\begin{array}{l}0.0973 \\
(0.0987)\end{array}$ & $\begin{array}{r}-0.2337 \\
\quad(0.1628)\end{array}$ \\
\hline & NATIONAL (nationally operating) & $\begin{array}{l}0.0191 \\
(0.1376)\end{array}$ & $\begin{array}{l}0.0534 \\
(0.1227)\end{array}$ & $\begin{array}{l}0.3182^{*} \\
(0.1759)\end{array}$ \\
\hline & BRANCH (number of branches) & $\begin{array}{c}0.2524^{* * *} \\
(0.0580)\end{array}$ & $\begin{array}{l}0.0233 \\
(0.0146)\end{array}$ & $\begin{array}{l}-0.0379 \\
\quad(0.0356)\end{array}$ \\
\hline & C_EXP (owner experience) & $\begin{array}{l}0.0115^{* *} \\
(0.0059)\end{array}$ & $\begin{array}{r}-0.0028 \\
(0.0060)\end{array}$ & $\begin{array}{r}-0.0256^{* * *} \\
(0.0092)\end{array}$ \\
\hline & C_FAGE (firm age) & $\begin{array}{l}-0.0070 \\
(0.0049)\end{array}$ & $\begin{array}{r}-0.0178^{* * *} \\
(0.0048)\end{array}$ & $\begin{array}{r}-0.0259^{* * *} \\
(0.0088)\end{array}$ \\
\hline & C_OAGE (owner age) & $\begin{array}{r}-0.0217^{* * *} \\
(0.0053)\end{array}$ & $\begin{array}{l}-0.0091 \\
(0.0056)\end{array}$ & $\begin{array}{r}-0.0157^{* *} \\
(0.0077)\end{array}$ \\
\hline & EDUC (owner higher education) & $\begin{array}{r}-0.1171 \\
(0.0936)\end{array}$ & $\begin{array}{r}-0.1418 \\
(0.0909)\end{array}$ & $\begin{array}{r}-0.3984^{* * *} \\
(0.1312)\end{array}$ \\
\hline$\beta$ 's & MINORITY (minority owner) & $\begin{array}{r}0.2858^{* *} \\
(0.1281)\end{array}$ & $\begin{array}{c}0.3747^{* * *} \\
(0.1283)\end{array}$ & $\begin{array}{c}0.5309^{* * *} \\
(0.1617)\end{array}$ \\
\hline & FEMALE (female owner) & $\begin{array}{r}-0.2596^{* *} \\
(0.0983)\end{array}$ & $\begin{array}{r}-0.0255 \\
(0.1039)\end{array}$ & $\begin{array}{c}0.2889^{* *} \\
(0.1370)\end{array}$ \\
\hline & FAMILY (family owned) & $\begin{array}{r}-0.3596^{* *} \\
(0.1480)\end{array}$ & $\begin{array}{r}-0.1692 \\
\quad(0.1175)\end{array}$ & $\begin{array}{l}0.0305 \\
(0.1894)\end{array}$ \\
\hline & Mid Atlantic & $\begin{array}{l}-0.3325 \\
\quad(0.2654)\end{array}$ & $\begin{array}{l}0.1600 \\
(0.2334)\end{array}$ & $\begin{array}{l}-0.1261 \\
\quad(0.3410)\end{array}$ \\
\hline & East N Central & $\begin{array}{l}-0.3253 \\
\quad(0.2650)\end{array}$ & $\begin{array}{l}-0.1002 \\
\quad(0.2293)\end{array}$ & $\begin{array}{r}-0.6491^{*} \\
(0.3484)\end{array}$ \\
\hline & West N Central & $\begin{array}{r}-0.4268 \\
\quad(0.2817)\end{array}$ & $\begin{array}{l}-0.0442 \\
\quad(0.2514)\end{array}$ & $\begin{array}{r}-0.1082 \\
\quad(0.3618)\end{array}$ \\
\hline & South Atlantic & $\begin{array}{r}-0.3157 \\
\quad(0.2582)\end{array}$ & $\begin{array}{l}0.0612 \\
\quad(0.2239)\end{array}$ & $\begin{array}{r}-0.0689 \\
\quad(0.3235)\end{array}$ \\
\hline & East S Central & $\begin{array}{r}-0.4936^{*} \\
(0.2944)\end{array}$ & $\begin{array}{l}0.0390 \\
\quad(0.2675)\end{array}$ & $\begin{array}{r}-0.3956 \\
(0.4138)\end{array}$ \\
\hline & West S Central & $\begin{array}{l}-0.4097 \\
\quad(0.2702)\end{array}$ & $\begin{array}{l}0.2094 \\
\quad(0.2429)\end{array}$ & $\begin{array}{l}0.5555^{*} \\
(0.3351)\end{array}$ \\
\hline & Mountain & $\begin{array}{r}-0.2353 \\
\quad(0.2941)\end{array}$ & $\begin{array}{l}0.2270 \\
\quad(0.2572)\end{array}$ & $\begin{array}{l}0.2468 \\
\quad(0.3652)\end{array}$ \\
\hline & Pacific & $\begin{array}{r}-0.4693^{*} \\
(0.2544) \\
\end{array}$ & $\begin{array}{l}0.0302 \\
(0.2224) \\
\end{array}$ & $\begin{array}{l}0.1884 \\
\quad(0.3162) \\
\end{array}$ \\
\hline
\end{tabular}




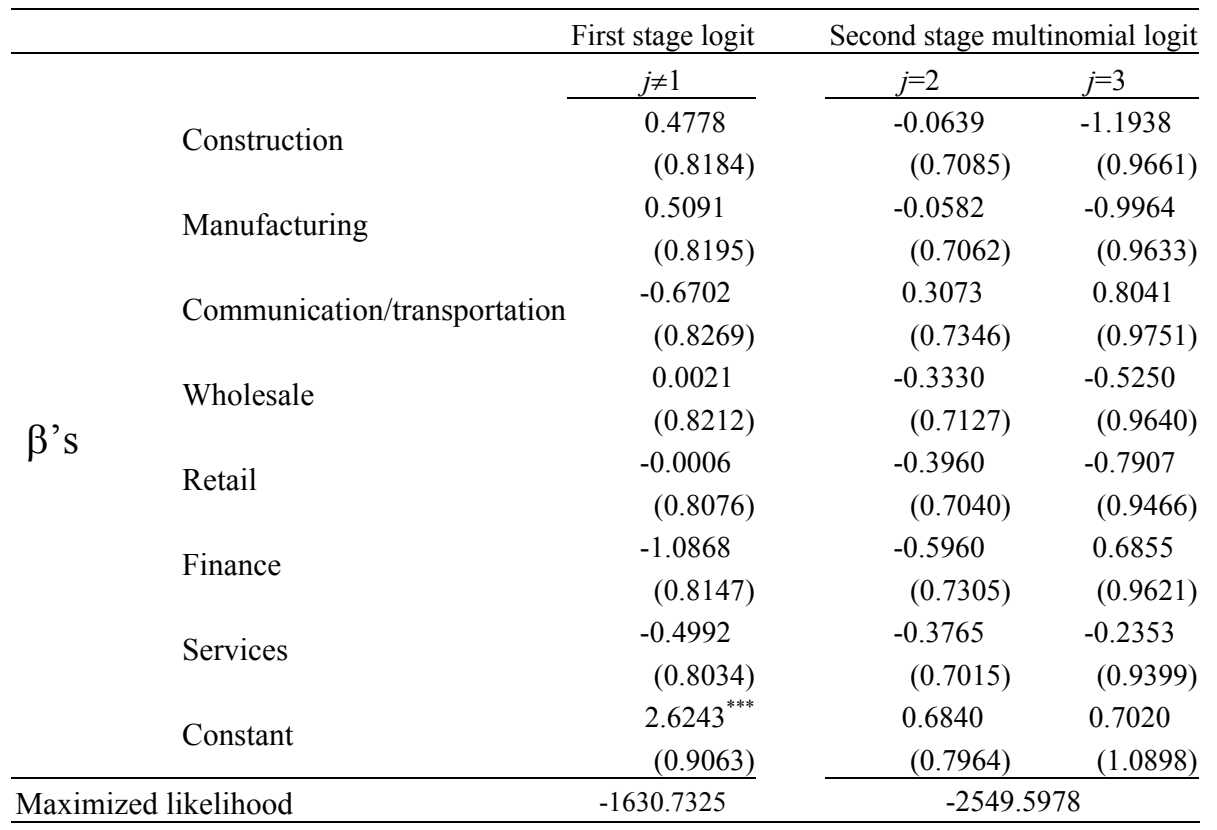


Table 5 Panel A Marginal effects for the nested logit model

\begin{tabular}{|c|c|c|c|c|c|c|c|}
\hline & \multicolumn{4}{|c|}{ Unconditional probabilities } & \multicolumn{3}{|c|}{ Conditional probabilities } \\
\hline & $\begin{array}{c}\text { No external } \\
\text { credit }\end{array}$ & $\begin{array}{c}\text { Trade credit } \\
\text { only }\end{array}$ & $\begin{array}{c}\text { Lending/ } \\
\text { Trade credit }\end{array}$ & $\begin{array}{c}\text { Lending } \\
\text { only }\end{array}$ & $\begin{array}{l}\text { Trade credit } \\
\text { only } \\
\end{array}$ & $\begin{array}{c}\text { Lending/ } \\
\text { Trade credit }\end{array}$ & $\begin{array}{c}\text { Lending } \\
\text { only }\end{array}$ \\
\hline RECORD (use of written record) & $\begin{array}{r}-2.3578 \\
(1.8602)\end{array}$ & $\begin{array}{l}0.5743 \\
(2.0093)\end{array}$ & $\begin{array}{c}2.5992 \\
(1.9822))\end{array}$ & $\begin{array}{r}-0.8157 \\
(1.3564)\end{array}$ & $\begin{array}{l}-0.5852 \\
(2.3981)\end{array}$ & $\begin{array}{l}2.3314 \\
(2.3415)\end{array}$ & $\begin{array}{r}-1.7462 \\
(1.8965)\end{array}$ \\
\hline $\begin{array}{l}\text { PCFMAN (computer use for } \\
\text { accounting) }\end{array}$ & $\begin{array}{r}-10.2432^{* * *} \\
(2.3365)\end{array}$ & $\begin{array}{l}4.3446^{* *} \\
(2.1494)\end{array}$ & $\begin{array}{l}8.9555^{* * *} \\
(2.7434)\end{array}$ & $\begin{array}{l}-3.0569^{*} \\
\quad(1.5706)\end{array}$ & $\begin{array}{l}-0.2841 \\
(2.4844)\end{array}$ & $\begin{array}{l}7.2413^{* * *} \\
(2.3394)\end{array}$ & $\begin{array}{r}-6.9571^{* * *} \\
(2.2377)\end{array}$ \\
\hline OWNER (managed by owner) & $\begin{array}{l}4.6758^{*} \\
(2.6262)\end{array}$ & $\begin{array}{l}-3.3592 \\
(2.8927)\end{array}$ & $\begin{array}{l}-4.5946 \\
(3.1143)\end{array}$ & $\begin{array}{l}3.2781 \\
(2.1424)\end{array}$ & $\begin{array}{r}-1.6368 \\
(3.2239)\end{array}$ & $\begin{array}{l}-3.7194 \\
\quad(3.1644)\end{array}$ & $\begin{array}{l}5.3562^{*} \\
(2.8317)\end{array}$ \\
\hline CORP (corporation) & $\begin{array}{r}-7.0972^{* * *} \\
(2.0446)\end{array}$ & $\begin{array}{l}2.9283 \\
(2.1165)\end{array}$ & $\begin{array}{l}5.1183^{* *} \\
(2.4794)\end{array}$ & $\begin{array}{l}-0.9494 \\
\quad(1.5268)\end{array}$ & $\begin{array}{l}-0.4392 \\
(2.3066)\end{array}$ & $\begin{array}{l}3.2807 \\
(2.2783)\end{array}$ & $\begin{array}{l}-2.8415 \\
(1.9777)\end{array}$ \\
\hline $\begin{array}{l}\text { NATIONAL (nationally } \\
\text { operating) }\end{array}$ & $\begin{array}{l}-0.3720 \\
(2.3808)\end{array}$ & $\begin{array}{l}-1.7151 \\
\quad(2.3837)\end{array}$ & $\begin{array}{l}-0.3953 \\
(2.5023)\end{array}$ & $\begin{array}{l}2.4825 \\
(1.7885)\end{array}$ & $\begin{array}{l}-2.6228 \\
(2.8018)\end{array}$ & $\begin{array}{l}-0.7628 \\
\quad(2.7131)\end{array}$ & $\begin{array}{l}3.3856 \\
(2.4456)\end{array}$ \\
\hline BRANCH (number of branches) & $\begin{array}{r}-3.8643^{* *} \\
(1.8448)\end{array}$ & $\begin{array}{l}1.6827^{* *} \\
(0.7592)\end{array}$ & $\begin{array}{l}1.8962^{* * *} \\
(0.6145)\end{array}$ & $\begin{array}{l}0.2854 \\
(0.4823)\end{array}$ & $\begin{array}{l}-0.1705 \\
\quad(0.4066)\end{array}$ & $\begin{array}{l}0.7386^{* *} \\
(0.3755)\end{array}$ & $\begin{array}{l}-0.5680 \\
(0.4909)\end{array}$ \\
\hline C_EXP (owner experience) & $\begin{array}{l}-0.1948 \\
(0.1282)\end{array}$ & $\begin{array}{l}0.2737^{* *} \\
(0.1237)\end{array}$ & $\begin{array}{l}0.1132 \\
(0.1212)\end{array}$ & $\begin{array}{r}-0.1920^{* *} \\
(0.0976)\end{array}$ & $\begin{array}{l}0.2505^{*} \\
(0.1433)\end{array}$ & $\begin{array}{l}0.0680 \\
(0.1415)\end{array}$ & $\begin{array}{r}-0.3186^{* *} \\
(0.1329)\end{array}$ \\
\hline C_FAGE (firm age) & $\begin{array}{l}0.0405 \\
(0.1017)\end{array}$ & $\begin{array}{c}0.3355^{* * *} \\
(0.1051)\end{array}$ & $\begin{array}{r}-0.2391^{* *} \\
(0.0996)\end{array}$ & $\begin{array}{l}-0.1368 \\
\quad(0.0855)\end{array}$ & $\begin{array}{c}0.4619^{* * *} \\
(0.1154)\end{array}$ & $\begin{array}{r}-0.2766^{* *} \\
(0.1190)\end{array}$ & $\begin{array}{c}-0.1853 \\
(0.1186)\end{array}$ \\
\hline C_OAGE (owner age) & $\begin{array}{c}0.3284^{* *} \\
(0.1647)\end{array}$ & $\begin{array}{l}0.0488 \\
(0.1215)\end{array}$ & $\begin{array}{r}-0.2058^{*} \\
(0.1142)\end{array}$ & $\begin{array}{r}-0.1714^{* *} \\
(0.0799)\end{array}$ & $\begin{array}{c}0.2717^{* *} \\
(0.1270)\end{array}$ & $\begin{array}{l}-0.1124 \\
\quad(0.1264)\end{array}$ & $\begin{array}{r}-0.1592 \\
(0.1011)\end{array}$ \\
\hline EDUC (owner higher education) & $\begin{array}{l}1.8901 \\
(1.7132)\end{array}$ & $\begin{array}{l}2.7033 \\
(1.7780)\end{array}$ & $\begin{array}{r}-1.5981 \\
(1.7445)\end{array}$ & $\begin{array}{r}-2.9952^{* *} \\
\quad(1.3176)\end{array}$ & $\begin{array}{r}4.8137^{* *} \\
(2.0542)\end{array}$ & $\begin{array}{r}-1.0832 \\
\quad(2.0343)\end{array}$ & $\begin{array}{r}-3.7305^{* *} \\
(1.7510)\end{array}$ \\
\hline MINORITY (minority owner) & $\begin{array}{r}-4.4522^{* *} \\
\quad(2.1674)\end{array}$ & $\begin{array}{r}-5.0594^{* *} \\
(2.5009)\end{array}$ & $\begin{array}{l}6.0276^{* *} \\
(2.7700)\end{array}$ & $\begin{array}{l}3.4840^{*} \\
(1.7837)\end{array}$ & $\begin{array}{r}-8.9385^{* * *} \\
(2.8453)\end{array}$ & $\begin{array}{l}5.3178^{*} \\
(2.8855)\end{array}$ & $\begin{array}{l}3.6207 \\
(2.2378)\end{array}$ \\
\hline FEMALE (female owner) & $\begin{array}{l}3.7229^{* *} \\
(1.8746)\end{array}$ & $\begin{array}{l}-2.7929 \\
(1.9387)\end{array}$ & $\begin{array}{c}-2.8284 \\
(1.9229)\end{array}$ & $\begin{array}{l}1.8984 \\
(1.3497)\end{array}$ & $\begin{array}{l}-1.5530 \\
(2.3173)\end{array}$ & $\begin{array}{l}-2.0843 \\
\quad(2.2642)\end{array}$ & $\begin{array}{l}3.6373^{*} \\
(1.8734)\end{array}$ \\
\hline FAMILY (family owned) & $\begin{array}{l}5.3103^{* *} \\
(2.3146)\end{array}$ & $\begin{array}{l}-0.0889 \\
(2.4215)\end{array}$ & $\begin{array}{r}-4.9326^{*} \\
(2.7955)\end{array}$ & $\begin{array}{r}-0.2887 \\
(1.7679)\end{array}$ & $\begin{array}{l}2.9069 \\
(2.6983)\end{array}$ & $\begin{array}{l}-3.7588 \\
(2.6886)\end{array}$ & $\begin{array}{l}0.8519 \\
(2.2970)\end{array}$ \\
\hline Mid Atlantic & $\begin{array}{l}5.5070 \\
(4.9956)\end{array}$ & $\begin{array}{l}-4.3479 \\
(4.3614)\end{array}$ & $\begin{array}{l}1.2956 \\
(4.9023)\end{array}$ & $\begin{array}{l}-2.4546 \\
\quad(2.7385)\end{array}$ & $\begin{array}{l}-2.1248 \\
\quad(5.2151)\end{array}$ & $\begin{array}{l}4.3045 \\
(5.3000)\end{array}$ & $\begin{array}{l}-2.1798 \\
(3.9936)\end{array}$ \\
\hline East N Central & $\begin{array}{l}5.0432 \\
(5.0130)\end{array}$ & $\begin{array}{l}1.8485 \\
(4.4615)\end{array}$ & $\begin{array}{r}-1.8703 \\
\quad(4.6423)\end{array}$ & $\begin{array}{l}-5.0214^{*} \\
(2.6289)\end{array}$ & $\begin{array}{l}6.1269 \\
(5.2310)\end{array}$ & $\begin{array}{l}0.0094 \\
\quad(5.1298)\end{array}$ & $\begin{array}{l}-6.1363^{*} \\
\quad(3.6731)\end{array}$ \\
\hline West N Central & $\begin{array}{l}7.0277 \\
(5.4719)\end{array}$ & $\begin{array}{l}-2.7795 \\
(4.6185)\end{array}$ & $\begin{array}{l}-2.3948 \\
\quad(4.8558)\end{array}$ & $\begin{array}{l}-1.8534 \\
\quad(2.9185)\end{array}$ & $\begin{array}{l}0.8788 \\
(5.6194)\end{array}$ & $\begin{array}{l}0.0767 \\
(5.5534)\end{array}$ & $\begin{array}{l}-0.9554 \\
(4.3765)\end{array}$ \\
\hline South Atlantic & $\begin{array}{l}4.9230 \\
(4.7504)\end{array}$ & $\begin{array}{l}-3.4999 \\
(4.2097)\end{array}$ & $\begin{array}{r}-0.1868 \\
\quad(4.5726)\end{array}$ & $\begin{array}{l}-1.2363 \\
\quad(2.7728)\end{array}$ & $\begin{array}{r}-1.4736 \\
(4.9968)\end{array}$ & $\begin{array}{l}1.9865 \\
\quad(5.0085)\end{array}$ & $\begin{array}{c}-0.5129 \\
\quad(4.0006)\end{array}$ \\
\hline East S Central & $\begin{array}{l}8.1567 \\
(5.8913)\end{array}$ & $\begin{array}{l}-3.0820 \\
(4.9259)\end{array}$ & $\begin{array}{l}-1.3356 \\
\quad(5.2132)\end{array}$ & $\begin{array}{l}-3.7391 \\
(2.9706)\end{array}$ & $\begin{array}{l}1.4567 \\
(6.0617)\end{array}$ & $\begin{array}{l}2.1853 \\
(6.0591)\end{array}$ & $\begin{array}{r}-3.6420 \\
(4.5135)\end{array}$ \\
\hline West S Central & $\begin{array}{l}6.5457 \\
(5.2807)\end{array}$ & $\begin{array}{r}-7.9743^{*} \\
(4.3697)\end{array}$ & $\begin{array}{l}-0.9176 \\
\quad(4.8129)\end{array}$ & $\begin{array}{l}2.3463 \\
(3.2817)\end{array}$ & $\begin{array}{l}-6.9816 \\
(5.2904)\end{array}$ & $\begin{array}{l}1.5656 \\
(5.4534)\end{array}$ & $\begin{array}{l}5.4161 \\
(4.8866)\end{array}$ \\
\hline Mountain & $\begin{array}{l}4.0120 \\
(5.4431)\end{array}$ & $\begin{array}{l}-5.3908 \\
(4.7449)\end{array}$ & $\begin{array}{l}1.3112 \\
(5.4050)\end{array}$ & $\begin{array}{l}0.0676 \\
(3.2487)\end{array}$ & $\begin{array}{l}-4.6916 \\
(5.6724)\end{array}$ & $\begin{array}{l}3.4766 \\
\quad(5.8143)\end{array}$ & $\begin{array}{l}1.2151 \\
(4.7434)\end{array}$ \\
\hline Pacific & $\begin{array}{l}7.6032 \\
(4.8550)\end{array}$ & $\begin{array}{r}-5.1093 \\
(4.1144)\end{array}$ & $\begin{array}{l}-2.7773 \\
(4.3784)\end{array}$ & $\begin{array}{l}0.2833 \\
(2.8321)\end{array}$ & $\begin{array}{r}-2.1680 \\
(4.9363)\end{array}$ & $\begin{array}{l}-0.2933 \\
\quad(4.9128)\end{array}$ & $\begin{array}{l}2.4613 \\
(4.1782)\end{array}$ \\
\hline Construction & $\begin{array}{l}-6.6174 \\
(11.4344)\end{array}$ & $\begin{array}{l}5.3093 \\
(14.3917)\end{array}$ & $\begin{array}{c}7.2607 \\
(15.8619))\end{array}$ & $\begin{array}{l}-5.9526 \\
(6.3157)\end{array}$ & $\begin{array}{l}2.9331 \\
(16.1572)\end{array}$ & $\begin{array}{l}6.0430 \\
(15.7630)\end{array}$ & $\begin{array}{l}-8.9761 \\
(7.8334)\end{array}$ \\
\hline Manufacturing & $\begin{array}{l}-7.2886 \\
(11.0936)\end{array}$ & $\begin{array}{c}5.3621 \\
(14.3298)\end{array}$ & $\begin{array}{l}6.8786 \\
(15.7444)\end{array}$ & $\begin{array}{l}-4.9521 \\
(6.6870)\end{array}$ & $\begin{array}{l}2.5324 \\
(16.0262)\end{array}$ & $\begin{array}{l}5.2676 \\
(15.5851)\end{array}$ & $\begin{array}{r}-7.8000 \\
(8.2162)\end{array}$ \\
\hline Communication/transportation & $\begin{array}{l}10.8532 \\
(16.9037)\end{array}$ & $\begin{array}{l}-12.7962 \\
(12.0126)\end{array}$ & $\begin{array}{l}-1.0416 \\
(14.5462)\end{array}$ & $\begin{array}{l}2.9847 \\
(9.0796)\end{array}$ & $\begin{array}{l}-11.7131 \\
(15.4317)\end{array}$ & $\begin{array}{l}3.4158 \\
(15.7967)\end{array}$ & $\begin{array}{l}8.2973 \\
(14.5452)\end{array}$ \\
\hline Wholesale & $\begin{array}{l}-0.0034 \\
(13.7994)\end{array}$ & $\begin{array}{c}4.1482 \\
(13.5999)\end{array}$ & $\begin{array}{l}-2.6057 \\
(14.1199)\end{array}$ & $\begin{array}{l}-1.5391 \\
(7.8649)\end{array}$ & $\begin{array}{l}5.3986 \\
(16.0128)\end{array}$ & $\begin{array}{l}-3.2070 \\
(14.5938)\end{array}$ & $\begin{array}{l}-2.1916 \\
(10.7203)\end{array}$ \\
\hline Retail & $\begin{array}{l}0.2431 \\
(13.6683)\end{array}$ & $\begin{array}{l}5.6335 \\
(13.3761)\end{array}$ & $\begin{array}{l}-2.6852 \\
(14.0479)\end{array}$ & $\begin{array}{l}-3.1913 \\
(7.5743)\end{array}$ & $\begin{array}{l}7.6008 \\
(15.7666)\end{array}$ & $\begin{array}{l}-3.1581 \\
(14.5771)\end{array}$ & $\begin{array}{l}-4.4427 \\
(10.2654)\end{array}$ \\
\hline Finance & $\begin{array}{l}20.4747 \\
(18.1010)\end{array}$ & $\begin{array}{l}-9.3584 \\
(11.7498)\end{array}$ & $\begin{array}{r}-16.2643 \\
\quad(10.5895)\end{array}$ & $\begin{array}{l}5.1480 \\
(9.2745)\end{array}$ & $\begin{array}{l}-1.2649 \\
(16.5796)\end{array}$ & $\begin{array}{l}-15.0697 \\
(12.2786)\end{array}$ & $\begin{array}{l}16.3346 \\
(16.4507)\end{array}$ \\
\hline Services & $\begin{array}{l}7.8781 \\
(13.7631) \\
\end{array}$ & $\begin{array}{l}-0.4160 \\
(13.1588)\end{array}$ & $\begin{array}{l}-6.6736 \\
(13.8357) \\
\end{array}$ & $\begin{array}{r}-0.7885 \\
(8.2144) \\
\end{array}$ & $\begin{array}{l}4.2684 \\
(15.6162) \\
\end{array}$ & $\begin{array}{c}-5.0419 \\
(14.6418)\end{array}$ & $\begin{array}{l}0.7735 \\
(11.2454) \\
\end{array}$ \\
\hline $\mathrm{N}$ & 735 & 1307 & 1046 & 389 & 1307 & 1046 & 389 \\
\hline
\end{tabular}


Table 5 Panel B Marginal effects for multinomial logit and nested multinomial models (conditional probabilities)

\begin{tabular}{|c|c|c|c|c|c|c|}
\hline & \multicolumn{3}{|c|}{ Multinomial logit } & \multicolumn{3}{|c|}{ Nested multinomial logit } \\
\hline & $\begin{array}{l}\text { Trade credit } \\
\text { only }\end{array}$ & $\begin{array}{c}\text { Lending/ } \\
\text { Trade credit }\end{array}$ & $\begin{array}{c}\text { Lending } \\
\text { only }\end{array}$ & $\begin{array}{l}\text { Trade credit } \\
\text { only } \\
\end{array}$ & $\begin{array}{c}\text { Lending/ } \\
\text { Trade credit }\end{array}$ & $\begin{array}{c}\text { Lending } \\
\text { only }\end{array}$ \\
\hline RECORD (use of written record) & $\begin{array}{l}-0.1883 \\
\quad(2.4192)\end{array}$ & $\begin{array}{l}2.4281 \\
(2.3437)\end{array}$ & $\begin{array}{l}-2.2399 \\
(1.9426)\end{array}$ & $\begin{array}{l}-0.3182 \\
\quad(2.4321)\end{array}$ & $\begin{array}{l}2.4173 \\
(2.3526)\end{array}$ & $\begin{array}{l}-2.0991 \\
(1.9723)\end{array}$ \\
\hline $\begin{array}{l}\text { PCFMAN (computer use for } \\
\text { accounting) }\end{array}$ & $\begin{array}{l}-0.7732 \\
\quad(2.4811)\end{array}$ & $\begin{array}{l}7.1013^{* * *} \\
(2.3256)\end{array}$ & $\begin{array}{r}-6.3282^{* * *} \\
(2.2024)\end{array}$ & $\begin{array}{l}-0.4910 \\
(2.5087)\end{array}$ & $\begin{array}{c}7.1833^{* * *} \\
(2.3442)\end{array}$ & $\begin{array}{r}-6.6922^{* * *} \\
(2.2806)\end{array}$ \\
\hline OWNER (managed by owner) & $\begin{array}{l}-4.0322 \\
(3.2120)\end{array}$ & $\begin{array}{l}-3.5694 \\
(3.1376)\end{array}$ & $\begin{array}{c}7.6016^{* * *} \\
(2.7347)\end{array}$ & $\begin{array}{l}-3.3374 \\
(3.2223)\end{array}$ & $\begin{array}{l}-3.7700 \\
(3.1599)\end{array}$ & $\begin{array}{l}7.1074^{* *} \\
(2.8053)\end{array}$ \\
\hline CORP (corporation) & $\begin{array}{l}-0.2512 \\
\quad(2.3211)\end{array}$ & $\begin{array}{l}3.4414 \\
\quad(2.2733)\end{array}$ & $\begin{array}{l}-3.1902 \\
\quad(1.9705)\end{array}$ & $\begin{array}{l}-0.2273 \\
(2.3286)\end{array}$ & $\begin{array}{l}3.4149 \\
(2.2830)\end{array}$ & $\begin{array}{l}-3.1876 \\
(2.0023)\end{array}$ \\
\hline NATIONAL (nationally operating) & $\begin{array}{r}-3.0486 \\
(2.7884)\end{array}$ & $\begin{array}{l}-0.2555 \\
\quad(2.6897)\end{array}$ & $\begin{array}{l}3.3041 \\
(2.4421)\end{array}$ & $\begin{aligned}-2.8996 \\
(2.8089)\end{aligned}$ & $\begin{array}{r}-0.4663 \\
(2.7067)\end{array}$ & $\begin{array}{l}3.3659 \\
(2.4923)\end{array}$ \\
\hline BRANCH (number of branches) & $\begin{array}{l}-0.1543 \\
(0.3990)\end{array}$ & $\begin{array}{l}0.7109^{*} \\
\quad(0.3653)\end{array}$ & $\begin{array}{l}-0.5565 \\
\quad(0.4670)\end{array}$ & $\begin{array}{r}-0.1667 \\
(0.4023)\end{array}$ & $\begin{array}{c}0.7237^{*} \\
(0.3701)\end{array}$ & $\begin{array}{l}-0.5570 \\
\quad(0.4777)\end{array}$ \\
\hline C_EXP (owner experience) & $\begin{array}{l}0.1681 \\
(0.1368)\end{array}$ & $\begin{array}{l}0.0688 \\
\quad(0.1338)\end{array}$ & $\begin{array}{l}-0.2369^{*} \\
\quad(0.1218)\end{array}$ & $\begin{array}{l}0.2064 \\
\quad(0.1406)\end{array}$ & $\begin{array}{r}0.0721 \\
(0.1377)\end{array}$ & $\begin{array}{r}-0.2786^{* *} \\
(0.1297)\end{array}$ \\
\hline C_FAGE (firm age) & $\begin{array}{r}0.4548^{* * *} \\
(0.1125)\end{array}$ & $\begin{array}{r}-0.2573^{* *} \\
(0.1143)\end{array}$ & $\begin{array}{l}-0.1975^{*} \\
(0.1180)\end{array}$ & $\begin{array}{c}0.4672^{* * *} \\
(0.1158)\end{array}$ & $\begin{array}{c}-0.2639^{* *} \\
(0.1176)\end{array}$ & $\begin{array}{l}-0.2034^{*} \\
\quad(0.1216)\end{array}$ \\
\hline C_OAGE (owner age) & $\begin{array}{l}0.2371^{*} \\
(0.1239)\end{array}$ & $\begin{array}{r}-0.1279 \\
(0.1222)\end{array}$ & $\begin{array}{l}-0.1092 \\
(0.0958)\end{array}$ & $\begin{array}{l}0.2547^{* *} \\
(0.1264)\end{array}$ & $\begin{array}{r}-0.1230 \\
(0.1246)\end{array}$ & $\begin{array}{r}-0.1317 \\
(0.1005)\end{array}$ \\
\hline EDUC (owner higher education) & $\begin{array}{l}4.8506^{* *} \\
(2.0924)\end{array}$ & $\begin{array}{r}-1.1148 \\
\quad(2.0582)\end{array}$ & $\begin{array}{l}-3.7357^{*} \\
(1.7763)\end{array}$ & $\begin{array}{l}4.9234^{* *} \\
(2.0930)\end{array}$ & $\begin{array}{r}-1.1024 \\
(2.0595)\end{array}$ & $\begin{array}{r}-3.8209^{* *} \\
(1.8022)\end{array}$ \\
\hline MINORITY (minority owner) & $\begin{array}{r}-10.1780^{* * *} \\
(2.8249)\end{array}$ & $\begin{array}{l}5.7499^{* *} \\
\quad(2.8961)\end{array}$ & $\begin{array}{l}4.4281^{*} \\
(2.3074)\end{array}$ & $\begin{array}{r}-9.7676^{* * *} \\
(2.8385)\end{array}$ & $\begin{array}{c}5.6497^{*} \\
(2.9015)\end{array}$ & $\begin{array}{l}4.1180^{*} \\
(2.3105)\end{array}$ \\
\hline FEMALE (female owner) & $\begin{array}{r}-1.0522 \\
(2.3276)\end{array}$ & $\begin{array}{l}-2.0849 \\
(2.2529)\end{array}$ & $\begin{array}{l}3.1372^{*} \\
(1.8684)\end{array}$ & $\begin{array}{r}-1.3558 \\
(2.3415)\end{array}$ & $\begin{array}{r}-2.0883 \\
(2.2659)\end{array}$ & $\begin{array}{l}3.4441^{*} \\
(1.9184)\end{array}$ \\
\hline FAMILY (family owned) & $\begin{array}{l}2.5918 \\
(2.7340)\end{array}$ & $\begin{array}{l}-4.0490 \\
\quad(2.6965)\end{array}$ & $\begin{array}{l}1.4572 \\
(2.2796)\end{array}$ & $\begin{array}{l}2.7298 \\
(2.7388)\end{array}$ & $\begin{array}{r}-3.9664 \\
(2.7046)\end{array}$ & $\begin{array}{l}1.2366 \\
(2.3298)\end{array}$ \\
\hline Mid Atlantic & $\begin{array}{r}-1.9339 \\
(5.2570)\end{array}$ & $\begin{array}{l}4.2268 \\
\quad(5.3120)\end{array}$ & $\begin{array}{l}-2.2929 \\
(4.0050)\end{array}$ & $\begin{array}{r}-1.9778 \\
(5.2719)\end{array}$ & $\begin{array}{r}4.2616 \\
(5.3297)\end{array}$ & $\begin{array}{r}-2.2839 \\
(4.0744)\end{array}$ \\
\hline East N Central & $\begin{array}{l}5.0769 \\
(5.2566)\end{array}$ & $\begin{array}{l}1.4786 \\
(5.1652)\end{array}$ & $\begin{array}{l}-6.5554^{*} \\
\quad(3.6945)\end{array}$ & $\begin{array}{l}5.7649 \\
(5.2772)\end{array}$ & $\begin{array}{r}1.1467 \\
(5.1691)\end{array}$ & $\begin{array}{l}-6.9115 \\
\quad(3.7427)\end{array}$ \\
\hline West N Central & $\begin{array}{l}1.7266 \\
(5.6537)\end{array}$ & $\begin{array}{l}-0.7735 \\
\quad(5.5187)\end{array}$ & $\begin{array}{l}-0.9531 \\
(4.3970)\end{array}$ & $\begin{array}{l}1.4358 \\
(5.6760)\end{array}$ & $\begin{array}{r}-0.4280 \\
(5.5536)\end{array}$ & $\begin{array}{r}-1.0078 \\
(4.4666)\end{array}$ \\
\hline South Atlantic & $\begin{array}{r}-0.0206 \\
(5.0393)\end{array}$ & $\begin{array}{l}1.5088 \\
(5.0003)\end{array}$ & $\begin{array}{l}-1.4882 \\
(3.9193)\end{array}$ & $\begin{array}{r}-0.6277 \\
\quad(5.0503)\end{array}$ & $\begin{array}{r}1.7385 \\
(5.0228)\end{array}$ & $\begin{array}{r}-1.1108 \\
\quad(4.0188)\end{array}$ \\
\hline East S Central & $\begin{array}{l}1.6944 \\
(6.1227)\end{array}$ & $\begin{array}{l}3.2616 \\
\quad(6.1066)\end{array}$ & $\begin{array}{l}-4.9560 \\
(4.3724)\end{array}$ & $\begin{array}{l}1.7867 \\
(6.1418)\end{array}$ & $\begin{array}{r}2.9506 \\
(6.1153)\end{array}$ & $\begin{array}{r}-4.7373 \\
(4.5020)\end{array}$ \\
\hline West S Central & $\begin{array}{l}-6.8030 \\
(5.3409)\end{array}$ & $\begin{array}{l}1.7306 \\
\quad(5.4476)\end{array}$ & $\begin{array}{l}5.0724 \\
(4.9226)\end{array}$ & $\begin{array}{l}-7.0676 \\
(5.3518)\end{array}$ & $\begin{array}{r}1.8001 \\
(5.4768)\end{array}$ & $\begin{array}{l}5.2674 \\
(5.0123)\end{array}$ \\
\hline Mountain & $\begin{array}{l}-5.7737 \\
(5.6988)\end{array}$ & $\begin{array}{l}3.9612 \\
\quad(5.8633)\end{array}$ & $\begin{array}{l}1.8125 \\
(4.8589)\end{array}$ & $\begin{array}{l}-5.4513 \\
\quad(5.7116)\end{array}$ & $\begin{array}{r}3.8138 \\
(5.8685)\end{array}$ & $\begin{array}{l}1.6375 \\
(4.8900)\end{array}$ \\
\hline Pacific & $\begin{array}{l}-1.1999 \\
(4.9805)\end{array}$ & $\begin{array}{l}-0.3406 \\
\quad(4.9131)\end{array}$ & $\begin{array}{l}1.5405 \\
(4.1156)\end{array}$ & $\begin{array}{r}-1.6916 \\
(4.9931)\end{array}$ & $\begin{array}{r}-0.3090 \\
(4.9325)\end{array}$ & $\begin{array}{l}2.0006 \\
(4.2210)\end{array}$ \\
\hline Construction & $\begin{array}{l}11.0691 \\
(16.0683)\end{array}$ & $\begin{array}{l}3.4158 \\
(15.5633)\end{array}$ & $\begin{array}{r}-14.4849 \\
(7.1498)\end{array}$ & $\begin{array}{l}8.5238 \\
(16.2689)\end{array}$ & $\begin{array}{r}4.8184 \\
(15.7287)\end{array}$ & $\begin{array}{r}-13.3422 \\
(7.5465)\end{array}$ \\
\hline Manufacturing & $\begin{array}{l}9.4961 \\
(16.0360)\end{array}$ & $\begin{array}{l}2.6028 \\
(15.4254)\end{array}$ & $\begin{array}{r}-12.0989 \\
(7.5057)\end{array}$ & $\begin{array}{l}7.1990 \\
(16.2048)\end{array}$ & $\begin{array}{r}3.9120 \\
(15.5717)\end{array}$ & $\begin{array}{r}-11.1111 \\
\quad(7.9494)\end{array}$ \\
\hline Communication/transportation & $\begin{array}{l}-8.6019 \\
(16.1202)\end{array}$ & $\begin{array}{l}1.5824 \\
(15.5261)\end{array}$ & $\begin{array}{l}7.0195 \\
(14.4338)\end{array}$ & $\begin{array}{l}-10.3015 \\
(15.9738)\end{array}$ & $\begin{array}{r}2.6996 \\
(15.6850)\end{array}$ & $\begin{array}{l}7.6019 \\
(14.8743)\end{array}$ \\
\hline Wholesale & $\begin{array}{l}11.4419 \\
(15.8107)\end{array}$ & $\begin{array}{l}-5.7227 \\
(14.2808)\end{array}$ & $\begin{array}{l}-5.7192 \\
(9.2463)\end{array}$ & $\begin{array}{l}9.0102 \\
(16.0944)\end{array}$ & $\begin{array}{r}-4.7402 \\
(14.4613)\end{array}$ & $\begin{array}{l}-4.2700 \\
(10.0712)\end{array}$ \\
\hline Retail & $\begin{array}{l}14.2482 \\
(15.3972)\end{array}$ & $\begin{array}{l}-5.9738 \\
(14.3061)\end{array}$ & $\begin{array}{l}-8.2744 \\
\quad(9.4292)\end{array}$ & $\begin{array}{l}11.7496 \\
(15.7256)\end{array}$ & $\begin{array}{r}-4.7656 \\
(14.4808)\end{array}$ & $\begin{array}{l}-6.9840 \\
(9.9182)\end{array}$ \\
\hline Finance & $\begin{array}{l}9.1966 \\
(16.6356)\end{array}$ & $\begin{array}{r}-17.8019 \\
\quad(11.9824)\end{array}$ & $\begin{array}{l}8.6053 \\
(14.7992)\end{array}$ & $\begin{array}{l}6.0250 \\
(16.9450)\end{array}$ & $\begin{array}{r}-17.0025 \\
(12.1073)\end{array}$ & $\begin{array}{l}10.9775 \\
(15.9690)\end{array}$ \\
\hline Services & $\begin{array}{l}10.4325 \\
(15.3232)\end{array}$ & $\begin{array}{l}-8.6412 \\
(14.5377)\end{array}$ & $\begin{array}{l}-1.7913 \\
(11.1428)\end{array}$ & $\begin{array}{l}7.9599 \\
(15.6352)\end{array}$ & $\begin{array}{r}-7.2374 \\
(14.6400)\end{array}$ & $\begin{array}{l}-0.7225 \\
(11.3912)\end{array}$ \\
\hline $\mathrm{N}$ & 1307 & 1046 & 389 & 1307 & 1046 & 389 \\
\hline
\end{tabular}


Table 6 Panel A Unconditional probabilities of financial choice when one dummy variable is held fixed

\begin{tabular}{|c|c|c|c|c|c|c|c|c|}
\hline & \multicolumn{4}{|c|}{ Dummy variable $=0$} & \multicolumn{4}{|c|}{ Dummy variable $=1$} \\
\hline & $\begin{array}{c}\text { No external } \\
\text { credits }\end{array}$ & $\begin{array}{l}\text { Trade credit I } \\
\text { only }\end{array}$ & $\begin{array}{l}\text { Lending/Trade } \\
\text { credit }\end{array}$ & $\begin{array}{c}\text { Lending } \\
\text { only }\end{array}$ & $\begin{array}{l}\text { No external } \\
\text { credits }\end{array}$ & $\begin{array}{l}\text { Trade credit I } \\
\text { only }\end{array}$ & $\begin{array}{l}\text { Lending/Trade } \\
\text { credit }\end{array}$ & $\begin{array}{c}\text { Lending } \\
\text { only }\end{array}$ \\
\hline RECORD (use of written record) & 22.9445 & 37.1596 & 28.0724 & 11.8235 & 20.5867 & 37.7339 & 30.6717 & 11.0078 \\
\hline PCFMAN (computer use for accounting) & 27.9457 & 34.7930 & 23.9425 & 13.3188 & 17.7025 & 39.1376 & 32.8980 & 10.2619 \\
\hline Owner (managed by owner) & 16.8665 & 40.6519 & 34.2903 & 8.1913 & 21.5423 & 37.2926 & 29.6957 & 11.4694 \\
\hline CORP (corporation) & 22.5901 & 37.0192 & 28.9679 & 11.4229 & 15.4929 & 39.9475 & 34.0862 & 10.4735 \\
\hline NATIONAL (nationally operating) & 21.2034 & 37.8273 & 30.1586 & 10.8106 & 20.8314 & 36.1122 & 29.7633 & 13.2931 \\
\hline BRANCH (number of branches) & - & - & - & - & - & - & - & - \\
\hline C_EXP (owner experience) & - & - & - & - & - & - & - & - \\
\hline C_FAGE (firm age) & - & - & - & - & - & - & - & - \\
\hline $\mathrm{C}^{-} \mathrm{OAGE}$ (owner age) & - & - & - & - & - & - & - & - \\
\hline EDUC (owner higher education) & 20.1782 & 36.1070 & 30.9830 & 12.7318 & 22.0683 & 38.8103 & 29.3849 & 9.7365 \\
\hline MINORITY (minority owner) & 21.7990 & 38.2786 & 29.3536 & 10.5688 & 17.3468 & 33.2192 & 35.3812 & 14.0529 \\
\hline FEMALE (female owner) & 20.0429 & 38.3766 & 30.9296 & 10.6509 & 23.7659 & 35.5836 & 28.1012 & 12.5493 \\
\hline FAMILY (family owned) & 16.4700 & 37.7347 & 34.3394 & 11.4559 & 21.7802 & 37.6458 & 29.4068 & 11.1672 \\
\hline Mid Atlantic & 20.5358 & 38.0859 & 29.9005 & 11.4778 & 26.0428 & 33.7379 & 31.1961 & 9.0232 \\
\hline East $\mathrm{N}$ Central & 20.5366 & 37.2495 & 30.3478 & 11.8662 & 25.5798 & 39.0980 & 28.4774 & 6.8448 \\
\hline West N Central & 20.6687 & 37.7441 & 30.2642 & 11.3230 & 27.6964 & 34.9646 & 27.8694 & 9.4695 \\
\hline South Atlantic & 20.3866 & 38.1480 & 30.0734 & 11.3920 & 25.3096 & 34.6481 & 29.8866 & 10.1556 \\
\hline East S Central & 20.7319 & 37.7171 & 30.1589 & 11.3921 & 28.8886 & 34.6351 & 28.8232 & 7.6530 \\
\hline West S Central & 20.5054 & 38.4447 & 30.1847 & 10.8652 & 27.0510 & 30.4704 & 29.2671 & 13.2115 \\
\hline Mountain & 20.9225 & 37.9339 & 29.9900 & 11.1536 & 24.9345 & 32.5431 & 31.3012 & 11.2212 \\
\hline Pacific & 19.7503 & 38.5684 & 30.6192 & 11.0621 & 27.3536 & 33.4591 & 27.8420 & 11.3454 \\
\hline Construction & 21.6942 & 37.0971 & 29.3166 & 11.8920 & 15.0768 & 42.4064 & 36.5774 & 5.9394 \\
\hline Manufacturing & 21.7058 & 37.1545 & 29.4010 & 11.7387 & 14.4172 & 42.5165 & 36.2796 & 6.7867 \\
\hline Communication/transportation & 20.7455 & 38.0683 & 30.1686 & 11.0176 & 31.5987 & 25.2721 & 29.1270 & 14.0022 \\
\hline Wholesale & 21.1384 & 37.2584 & 30.3152 & 11.2880 & 21.1350 & 41.4065 & 27.7095 & 9.7490 \\
\hline Retail & 21.1331 & 36.3642 & 30.5929 & 11.9099 & 21.3761 & 41.9977 & 27.9076 & 8.7185 \\
\hline Finance & 19.9887 & 38.1007 & 31.1580 & 10.7527 & 40.4633 & 28.7422 & 14.8937 & 15.9007 \\
\hline Services & 17.7434 & 37.7870 & 32.9433 & 11.5264 & 25.6215 & 37.3709 & 26.2697 & 10.7379 \\
\hline $\mathrm{N}$ & 735 & 1307 & 1046 & 389 & 735 & 1307 & 1046 & 389 \\
\hline
\end{tabular}


Table 6 Panel B Conditional probabilities of financial choice when one dummy variable is held fixed

\begin{tabular}{|c|c|c|c|c|c|c|}
\hline & \multicolumn{3}{|c|}{ Dummy variable $=0$} & \multicolumn{3}{|c|}{ Dummy variable $=1$} \\
\hline & $\begin{array}{l}\text { Trade credit } \\
\text { only }\end{array}$ & $\begin{array}{l}\text { iding/Trade } \\
\text { credit }\end{array}$ & $\begin{array}{c}\begin{array}{c}\text { Lending } \\
\text { only }\end{array} \\
\end{array}$ & $\begin{array}{l}\text { Trade credit I } \\
\text { only }\end{array}$ & $\begin{array}{l}\text { nding/Trade } \\
\text { credit }\end{array}$ & $\begin{array}{c}\begin{array}{c}\text { Lending } \\
\text { only }\end{array} \\
\end{array}$ \\
\hline RECORD (use of written record & 48.1415 & 35.2245 & 16.6340 & 47.5563 & 37.5559 & 14.8878 \\
\hline PCFMAN (computer use for accounting) & 47.9638 & 32.0512 & 19.9851 & 47.6797 & 39.2924 & 13.0279 \\
\hline Owner (managed by owner) & 49.1842 & 40.4383 & 10.3776 & 47.5474 & 36.7188 & 15.7338 \\
\hline CORP (corporation) & 47.8625 & 36.3097 & 15.8278 & 47.4234 & 39.5904 & 12.9863 \\
\hline NATIONAL (nationally operating) & 48.0205 & 37.1492 & 14.8303 & 45.3977 & 36.3864 & 18.2159 \\
\hline BRANCH (number of branches) & - & - & - & - & - & - \\
\hline C_EXP (owner experience) & - & - & - & - & - & - \\
\hline C_FAGE (firm age) & - & - & - & - & - & - \\
\hline C_OAGE (owner age) & - & - & - & - & - & - \\
\hline EDUC (owner higher education) & 45.1594 & 37.6614 & 17.1792 & 49.9732 & 36.5782 & 13.4487 \\
\hline MINORITY (minority owner) & 48.9472 & 36.3988 & 14.6540 & 40.0086 & 41.7166 & 18.2747 \\
\hline FEMALE (female owner) & 48.1361 & 37.6667 & 14.1972 & 46.5830 & 35.5824 & 17.8345 \\
\hline FAMILY (family owned) & 45.1909 & 40.2611 & 14.5480 & 48.0977 & 36.5024 & 15.3999 \\
\hline Mid Atlantic & 47.9108 & 36.5315 & 15.5576 & 45.7861 & 40.8361 & 13.3779 \\
\hline East N Central & 46.8350 & 37.0870 & 16.0781 & 52.9619 & 37.0963 & 9.9418 \\
\hline West N Central & 47.5819 & 37.0462 & 15.3718 & 48.4607 & 37.1229 & 14.4164 \\
\hline South Atlantic & 47.9159 & 36.6978 & 15.3863 & 46.4423 & 38.6844 & 14.8733 \\
\hline East S Central & 47.5663 & 36.9351 & 15.4986 & 49.0230 & 39.1204 & 11.8566 \\
\hline West S Central & 48.4265 & 36.9079 & 14.6656 & 41.4449 & 38.4734 & 20.0817 \\
\hline Mountain & 47.9734 & 36.8183 & 15.2083 & 43.2818 & 40.2948 & 16.4234 \\
\hline Pacific & 48.1263 & 37.1256 & 14.7480 & 45.9584 & 36.8323 & 17.2093 \\
\hline Construction & 47.3873 & 36.3854 & 16.2273 & 50.3204 & 42.4284 & 7.2512 \\
\hline Manufacturing & 47.4783 & 36.4976 & 16.0241 & 50.0107 & 41.7653 & 8.2241 \\
\hline Communication/transportation & 48.1062 & 36.9338 & 14.9599 & 36.3931 & 40.3497 & 23.2573 \\
\hline Wholesale & 47.2816 & 37.2887 & 15.4297 & 52.6802 & 34.0817 & 13.2381 \\
\hline Retail & 46.1258 & 37.6228 & 16.2515 & 53.7265 & 34.4647 & 11.8088 \\
\hline Finance & 47.7276 & 38.0012 & 14.2712 & 46.4627 & 22.9315 & 30.6058 \\
\hline Services & 45.9520 & 39.1521 & 14.8959 & 50.2204 & 34.1102 & 15.6694 \\
\hline $\mathrm{N}$ & 1307 & 1046 & 389 & 1307 & 1046 & 389 \\
\hline
\end{tabular}

